\title{
Uaktualnienie praktycznego przewodnika EHRA dotyczącego stosowania doustnych antykoagulantów niebędących antagonistami witaminy K u pacjentów z niezastawkowym migotaniem przedsionków
}

\author{
Updated EHRA practical guide on the use of non-vitamin K antagonist \\ oral anticoagulants in patients with non-valvular atrial fibrillation
}

Filip M. Szymański

I Katedra i Klinika Kardiologii, Warszawski Uniwersytet Medyczny, Warszawa

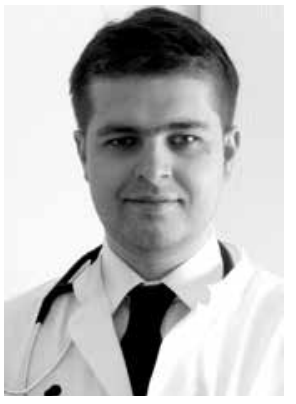

\section{WPROWADZENIE}

W 2013 r. European Heart Rhythm Association (EHRA) wydało praktyczny przewodnik dotyczący zasad stosowania nowych doustnych antykoagulantów (NOAC) w praktyce klinicznej $[1,2]$. Jeszcze wtedy skrót NOAC tłumaczyliśmy jako nowe doustne antykoagulanty (new oral anitcoagulants), ale w 2014 r. Grupa Robocza Europejskiego Towarzystwa Kardiologicznego (ESC) wydała stanowisko, w którym zaleca dalsze używanie skrótu NOAC, który jednak powinien być rozwijany jako doustne antykoagulanty niebędące antagonistami witaminy $\mathrm{K}$ (non-vitamin K antagonist oral anticoagulants) [3]. Zalecana zmiana jest podyktowana faktem, że od czasu wprowadzenia na rynek NOAC, leki te zostały doskonale przebadane klinicznie i mamy coraz większe doświadczenie w ich stosowaniu, w związku z czym nie powinny być już nazywane lekami nowymi. Niemniej jednak, odpowiednie wykorzystanie w praktyce klinicznej wymaga stałej aktualizacji wiedzy, między innymi dlatego, że ciągle pojawiają się nowe badania dotyczące zarówno skuteczności oraz bezpieczeństwa, jak i innych aspektów stosowania NOAC, takich jak np. odwracanie ich działania.

Niniejsze podsumowanie stanowi tłumaczenie i zestawienie najważniejszych kwestii poruszonych w nowym dokumencie EHRA — uaktualnieniu „Praktycznego przewodnika stosowania NOAC u pacjentów z niezastawkowym migo- taniem przedsionków", który wydano pod koniec 2015 r. [4]. Uzupełnieniem tego opracowania jest oficjalna strona internetowa prowadzona przez EHRA (www.NOACforAF.eu), na której na bieżąco są publikowane nowe doniesienia na temat NOAC.

\section{DEFINICJA NIEZASTAWKOWEGO MIGOTANIA PRZEDSIONKÓW I GRUPY PACJENTÓW, U KTÓRYCH MOŻNA ROZPOCZĄ̨Ć LECZENIE ZA POMOCĄ NOAC}

Niezastawkowe migotanie przedsionków (AF) dotyczy przypadków AF, które występują w sytuacji braku mechanicznej protezy zastawek serca oraz niewystępowania umiarkowanej do ciężkiej stenozy zastawki mitralnej (zwykle pochodzenia reumatycznego (tab. 1). Obie wymienione powyżej grupy pacjentów wykluczono ze wszystkich badań dotyczących NOAC. Migotanie przedsionków u osób z biologicznymi zastawkami oraz po operacyjnej korekcie wad zastawkowych stanowi niejako „szarą strefę", ponieważ tych chorych włączono tylko do niektórych badań dotyczących NOAC. Niemniej jednak, mogą być oni odpowiednimi kandydatami do leczenia za pomocą NOAC, co omówiono poniżej. Nie dysponujemy danymi dotyczącymi pacjentów po przezskórnych interwencjach na zastawce aortalnej [przezskórnej plastyce zastawki aortalnej (PTAV) lub przezcewnikowej implantacji zastawki aortalnej (TAVI)]. Skoro jednak w przypadku niewystępowania AF u tych chorych nie jest wymagane doustne leczenie przeciwzakrzepowe, to wydają się oni być odpowiednimi kandydatami do 
Tabela 1. Wskazania i przeciwwskazania do stosowania doustnych antykoagulantów niebędących antagonistami witaminy $\mathrm{K}$

$\begin{array}{lcc}\text { Mechaniczna sztuczna zastawka } & \text { Stosowanie dopuszczalne } & \text { Stosowanie przeciwwskazane } \\ \text { Umiarkowana do ciężkiej stenoza mitralna } & \\ \text { (zwykle o etiologii reumatycznej) } & \\ \text { Łagodna do umiarkowanej wada innej, } & \checkmark \\ \text { własnej zastawki } & \checkmark \\ \text { Ciężka stenoza aortalna } & \text { (ograniczone dane - większość jest } \\ & \text { leczona interwencyjnie) } \\ \text { Biologiczna sztuczna zastawka } & \checkmark \\ \text { Przebyta operacja zastawki mitralnej } & \text { (poza okresem 3 miesięcy po operacji) } \\ \text { Przezskórna walwuloplastyka zastawki aortalnej } & \checkmark \\ \text { lub przezskórna implantacja zastawki aortalnej } & \text { (poza okresem 3-6 miesięcy po operacji) } \\ & \checkmark \\ \text { Kardiomiopatia przerostowa } & \text { może się okazać konieczne pojedyncze } \\ & \text { lub podwójne leczenie przeciwpłytkowe; } \\ & \text { należy rozważyć ryzyko krwawień) } \\ & \checkmark \\ & \text { (ale brakuje danych prospektywnych) }\end{array}$

przyjmowania NOAC w przypadku AF. Niemniej jednak, PTAV lub TAVI wymaga obowiązkowego stosowania pojedynczej lub podwójnej terapii przeciwpłytkowej (DAPT) [5]. Jednoczesne leczenie przeciwzakrzepowe i przeciwpłytkowe zwiększa ryzyko krwawień. Nie dysponujemy obecnie prospektywnymi danymi na temat tego, jaka jest najlepsza strategia terapii u takich pacjentów (analogicznie do ostrych zespołów wieńcowych opisanych w części „Pacjenci z migotaniem przedsionków i chorobą wieńcową”). Analogiczne powody sprawiają, że pacjenci z AF i kardiomiopatią przerostową wydają się kwalifikować do leczenia za pomocą NOAC, chociaż istnieje bardzo mało doświadczeń ze stosowaniem NOAC w takich przypadkach [5].

\section{PRAKTYCZNY SCHEMAT ROZPOCZYNANIA I KONTYNUOWANIA STOSOWANIA NOAC \\ Wybór rodzaju leczenia przeciwzakrzepowego i jego wdrożenie}

Wskazania do leczenia przeciwzakrzepowego i wybór między NOAC a VKA. Przed przepisaniem NOAC pacjentowi z AF na podstawie analizy bilansu ryzyka i korzyści należy ustalić, czy leczenie przeciwzakrzepowe jest wskazane. Wyboru metody terapii przeciwzakrzepowej [antagoniści witaminy K (VKA) lub NOAC; rodzaj NOAC] trzeba dokonać, opierając się na wskazaniach zatwierdzonych przez organy regulacyjne oraz na wytycznych towarzystw naukowych. Wymagana jest ocena funkcji nerek, wyrażona przez szacunkowy wskaźnik przesączania kłębuszkowego obliczany ze wzoru Cockcrofta-Gaulta, ponieważ dawkowanie i możliwość stosowania NOAC ustala się na podstawie wartości tego wskaźnika (patrz „Pacjenci z przewlekłą chorobą nerek"). Ponadto przed wyborem leczenia należy uwzględnić informacje zawarte w charakterystyce produktu leczniczego (ChPL) i charakterystykę kliniczną pacjenta, a także jego preferencje [6-8].

W europejskich wytycznych preferuje się NOAC nad VKA w prewencji udaru mózgu u pacjentów z AF na podstawie ogólnych korzyści klinicznych związanych z ich stosowaniem [9].

Wybór odpowiedniego typu i dawki NOAC. W tabeli 2 przedstawiono listę NOAC zarejestrowanych w celu zapobiegania udarowi mózgu u pacjentów z AF. NOAC nie mają dokładnie identycznych wskazań i dostępności w różnych krajach. Sprawa wyboru konkretnego NOAC i jego dawkowania zależy również od przyjmowanych równocześnie przez chorego innych leków, ponieważ niektóre NOAC mogą być przeciwwskazane lub stwarzać ryzyko wystąpienia niekorzystnych interakcji z innymi lekami (patrz niżej). Również wiek pacjenta, masa ciała, czynność nerek (patrz „Pacjenci z przewlekłą chorobą nerek") oraz inne choroby współistniejące wpływają na wybór NOAC (patrz niżej). U niektórych pacjentów inhibitory pompy protonowej (IPP) można uznać za wskazane w celu zmniejszenia ryzyka krwawienia z przewodu pokarmowego, zwłaszcza u osób z wywiadem takiego krwawienia lub chorobą wrzodową.

\section{Jak zorganizować wizyty kontrolne?}

Wizyty kontrolne pacjentów z AF leczonych doustnymi lekami przeciwzakrzepowymi powinny być z góry określone i ustalone między lekarzami różnych specjalności zajmują- 
Tabela 2. Doustne antykoagulanty niebędące antagonistami witaminy K zarejestrowane w prewencji zatorów obwodowych i udaru u pacjentów z niezastawkowym migotaniem przedsionków

\begin{tabular}{|lcccc} 
& Dabigatran & Apiksaban & Edoksaban & Riwaroksaban \\
\hline Sposób działania & Bezpośredni inhibitor & Inhibitor aktywowanego & Inhibitor aktywowanego & Inhibitor aktywowanego \\
& trombiny & czynnika Xa & czynnika Xa & czynnika Xa \\
Dawka & $150 \mathrm{mg} \mathrm{bid}$ & $5 \mathrm{mg} \mathrm{bid}$ & $60 \mathrm{mg} \mathrm{qd} \mathrm{d}^{* *}$ & $20 \mathrm{mg} \mathrm{qd}$ \\
& $110 \mathrm{mg} \mathrm{bid}(75 \mathrm{mg} \mathrm{bid})$ & $2,5 \mathrm{mg} \mathrm{bid}$ & $30 \mathrm{mg} \mathrm{qd}$ & $15 \mathrm{mg} \mathrm{qd}$ \\
Badanie kliniczne trzeciej fazy & RE-LYa & ARISTOTLE & ENGAGE-AF & ROCKET-AF \\
& & AVERROESc & & \\
\end{tabular}

bid (łac. bis in die) — dwa razy na dobę; qd (łac. quaque die) — raz na dobę

*Dawka zrejestrowana tylko w Stanach Zjednoczonych; **U pacjentów z klirensem kreatyniny $>95 \mathrm{ml} / \mathrm{min}$ edoksaban powinien być stosowany

z ostrożnością. Europejska Agencja Leków (EMA) zaleca, aby „u pacjentów z wysokim klirensem kreatyniny edoksaban był stosowany z zachowaniem ostrożności i indywidualną oceną ryzyka zakrzepowo-zatorowego oraz ryzyka krwawień"

aConnolly SJ, Ezekowitz MD, Yusuf S et al. Dabigatran versus warfarin in patients with atrial fibrillation. N Engl J Med, 2009; 361: 1139-1151.

${ }^{b}$ Granger CB, Alexander JH, McMurray JJ et al. Apixaban versus warfarin in patients with atrial fibrillation. N Engl J Med, 2011 ; $365: 981-992$.

'Connolly SJ, Eikelboom J, Joyner C et al. Apixaban in patients with atrial fibrillation. N Engl J Med, 2011; 364: 806-817.

dGiugliano RP, Ruff CT, Braunwald E et al. Edoxaban versus warfarin in patients with atrial fibrillation. N Engl J Med, 2013; 369: 2093-2104.

epatel MR, Mahaffey KW, Garg J et al. Rivaroxaban versus warfarin in nonvalvular atrial fibrillation. N Engl J Med, $2011 ; 365: 883-891$.

cymi się chorym. Wszystkie antykoagulanty wykazują pewne interakcje z innymi lekami i mogą spowodować poważne krwawienie. Wdrożenie terapii lekami z tej klasy wymaga czujności, również dlatego, że pacjent może się cechować złym ogólnym stanem zdrowia, a NOAC są lekami charakteryzującymi się potencjalnym ryzykiem poważnych powikłań. Pacjenci powinni zgłaszać się regularnie na wizyty kontrolne i regularną ocenę ich leczenia, najlepiej co miesiąc na początku terapii i co 3 miesiące w późniejszym okresie. Schemat przedstawiony na rycinie 1 może zostać wdrożony przez lekarzy podstawowej opieki zdrowotnej z doświadczeniem w tym zakresie i/lub odpowiednich specjalistów. W niektórych ośrodkach korzystna może być również terapia pacjentów w ośrodkach koordynowanych przez pielęgniarki [10, 11]. Wraz ze wzrostem doświadczenia klinicznego w stosowaniu NOAC odstępy czasu między wizytami kontrolnymi mogą być wydłużane w zależności od indywidualnych i lokalnych czynników [12].

Niewielkie krwawienia są szczególnym problemem u pacjentów leczonych każdym antykoagulantem. Najlepszą metodą radzenia sobie z tym powikłaniem jest standardowe, miejscowe kontrolowanie krwawienia, bez konieczności zaprzestania terapii czy redukcji dawki leku. Małe krwawienie nie musi oznaczać dużego ryzyka krwawienia. Większość niewielkich krwawień jest przemijająca i najlepiej klasyfikować je jako swego rodzaju „uciążliwość”. W niektórych przypadkach (np. krwawień z nosa) użyteczne może być leczenie przyczynowe, takie jak przyżeganie tętnic nosowych. Oczywiście, gdy takie krwawienie występuje często, jakość życia pacjenta może ulec pogorszeniu i dany sposób leczenia lub dawka leku mogą wymagać weryfikacji, ale takie działanie powinno być podejmowane bardzo ostrożnie, aby uniknąć pozbawienia chorego korzyści z zapobiegania powikłaniom zakrzepowo-zatorowym. U wielu pacjentów, którzy zgłaszają uciążliwe krwawienia lub drobne działania niepożądane, korzystna może być zmiana na inny lek.

\section{JAK MIERZYĆ SIŁĘ DZIAŁANIA PRZECIWZAKRZEPOWEGO PODCZAS LECZENIA NOAC?}

Doustne antykoagulanty niebędące antagonistami witaminy $\mathrm{K}$ nie wymagają rutynowego monitorowania parametrów krzepnięcia. Ani dawka leku, ani czas między poszczególnymi dawkami nie powinny być modyfikowane w odpowiedzi na zmiany laboratoryjnych parametrów krzepnięcia w odniesieniu do zarejestrowanych obecnie wskazań do stosowania NOAC. Niemniej jednak ilościowa ocena stężenia leków i ich działania antykoagulacyjnego może być istotna w sytuacjach zagrożenia życia, takich jak poważne incydenty zakrzepowe lub krwotoczne, potrzeba pilnej operacji lub inne specyficzne sytuacje kliniczne, takie jak ostra niewydolność wątroby czy nerek lub wystąpienie przedawkowania bądź interakcji z innymi lekami.

Podczas interpretacji wyników oznaczeń koagulogramu u pacjentów leczonych NOAC dużo istotniejsze niż w przypadku monitorowania VKA jest ustalenie, jaki jest odstęp czasu od przyjęcia ostatniej dawki NOAC do pobrania próbki krwi. Maksymalny wpływ działania NOAC na parametry krzepnięcia będzie miał miejsce w momencie osiągnięcia maksymalnego stężenia leku we krwi, czyli ok. 3 h po przyjęciu każdego z leków. Wynik oznaczenia parametrów krzepnięcia uzyskany z próbki krwi pobranej 3 h po przyjęciu NOAC [maksymalne stężenie we krwi (peak level)] będzie wskazywać na znacznie większe działanie NOAC niż efekt uzyskany po osiągnięciu stabilnego stężenia leku w surowicy (trough level), np. po 12 h czy 24 h od przyjęcia tej samej dawki leku. Ponadto, w zależności od profilu klinicznego pacjenta, powinno się oszacować czas półtrwania w fazie eli- 


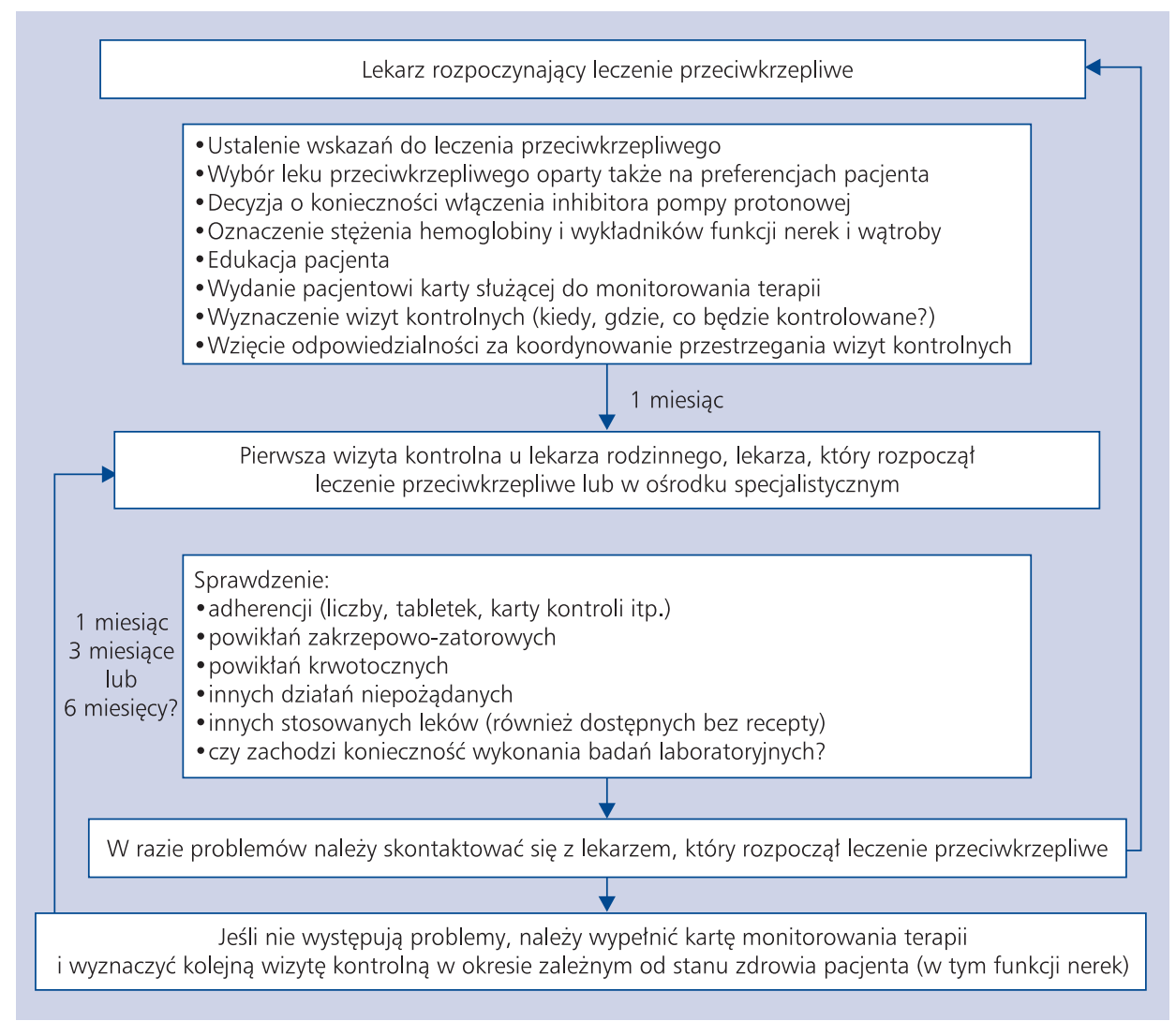

Rycina 1. Planowanie wizyt kontrolnych u pacjentów przyjmujących doustne antykoagulanty niebędące antagonistami witaminy K. Konieczne jest upewnienie się, że chorzy stosują leki regularnie i jest to dla nich bezpieczne. Pomocne mogą w tym być specjalne karty służące do monitorowania terapii, w których odnotowuje się wszystkie wizyty kontrolne, wyniki badań i zmiany leczenia. Pozwala to na lepsze przekazywanie informacji między lekarzami wszystkich specjalności zajmującymi się pacjentem

minacji, ponieważ może być on wydłużony u osób starszych i z zaburzoną funkcją nerek (patrz „Pacjenci z przewlekłą chorobą nerek"). Należy zatem starannie ustalić opóźnienie między przyjęciem leku i pobieraniem próbek krwi, gdy wykonuje się monitorowanie kliniczne. Omówienie zasad interpretacji wszystkich testów koagulacji w przypadku różnych NOAC zawarto w tabeli 3.

\section{MOŻLIWE INTERAKCJE Z INNYMI LEKAMI I FARMAKOKINETYKA NOAC}

Leczenie za pomocą VKA wymaga starannego rozważenia wielu interakcji z żywnością i lekami. Mimo dużych oczekiwań dotyczących mniejszej liczby interakcji z NOAC, lekarze przepisując NOAC, muszą brać pod uwagę właściwości farmakokinetyczne równoczesnego podawania innych leków oraz obecność chorób współistniejących. Poniżej przedstawiono proste instrukcje na temat postępowania w takich sytuacjach. Jednak każdy pacjent może wymagać jeszcze bardziej indywidualnego podejścia, zwłaszcza gdy występuje kombinacja czynników zakłócających farmakokinetykę leku. Ponadto wiedza dotycząca interakcji (wpływu NOAC na stężenia w osoczu i/lub na efekty kliniczne) rozwija się, a nowe informacje mogą modyfikować istniejące już zalecenia.

Dane dotyczące wchłaniania, metabolizmu i wydalania poszczególnych NOAC podsumowano w tabeli 4. Informacje te powinny być zawsze dostępne dla każdego zaangażowanego w leczenie pacjenta stosującego NOAC.

Nie wszystkie sytuacje kliniczne są objęte wspomnianymi algorytmami. Opracowano podejście obejmujące wyszczególnianie trzech poziomów ostrożności dla interakcji z innymi lekami lub innymi czynnikami klinicznymi, które mogą wpływać na stężenie NOAC w osoczu lub rokowanie:

- czerwone - interakcje wykluczające użycie danego NOAC;

- pomarańczowe - zalecenie, aby dostosować dawkę NOAC, ponieważ interakcje te mogą spowodować zmiany stężenia NOAC w osoczu, które mogą mieć skutki kliniczne;

— żółte - zalecenie, aby zachować oryginalną dawkę, chyba że występują dwie lub więcej towarzyszące interakcje oznaczone kolorem żółtym. Wystąpienie $\geq 2$ interakcji oznaczoych kolorem żółtym wymaga fachowej oceny 
Tabela 3. Interpretacja parametrów krzepnięcia krwi u pacjentów leczonych różnymi antykoagulantami

\begin{tabular}{|c|c|c|c|c|}
\hline & Dabigatran & Apiksaban & Edoksaban & Riwaroksaban \\
\hline $\begin{array}{l}\text { Najwyższe stężenie } \\
\text { w osoczu (peak level) }\end{array}$ & 2 h po przyjęciu & 1-4 h po przyjęciu & 1-2 h po przyjęciu & 2-4 h po przyjęciu \\
\hline $\begin{array}{l}\text { Stabilne stężenie } \\
\text { w osoczu (trough level) }\end{array}$ & 12 h po przyjęciu & 12 h po przyjęciu & 24 h po przyjęciu & 24 h po przyjęciu \\
\hline Czas protrombinowy & Nieużyteczny & $\begin{array}{l}\text { Wydłużony, ale występują } \\
\text { wahania i nie jest zna- } \\
\text { ny związek z ryzykiem } \\
\text { krwawień }\end{array}$ & $\begin{array}{l}\text { Wydłużony, ale nie jest } \\
\text { znany związek z ryzykiem } \\
\text { krwawień }\end{array}$ & $\begin{array}{l}\text { Wydłużony, ale nie jest } \\
\text { znany związek z ryzykiem } \\
\text { krwawień }\end{array}$ \\
\hline INR & Nieużyteczny & Nieużyteczny & Nieużyteczny & Nieużyteczny \\
\hline aPTT & $\begin{array}{l}\text { Zakres norm (10-90 P) po osią- } \\
\text { gnięciu stabilnego stężenia } \\
\text { w surowicy: } \\
\text { - } 150 \mathrm{mg}-40,3-76,4 \mathrm{~s} \\
\text { - } 110 \mathrm{mg}-37,5-60,9 \mathrm{~s} \\
\text { Wydłużenie aPTT po osiągnięciu } \\
\text { stabilnego stężenia w osoczu: } \\
\text { > } 2 \text { × ULN może wskazywać na } \\
\text { wzrost ryzyka krwawień }\end{array}$ & Nieużyteczny & $\begin{array}{l}\text { Wydłużony, ale nie jest } \\
\text { znany związek z ryzykiem } \\
\text { krwawień }\end{array}$ & Nieużyteczny \\
\hline dTT & $\begin{array}{l}\text { Brak danych na temat zakresu } \\
\text { norm, pochodzących z bada- } \\
\text { nia RELY, ale dTT } \geq 65 \text { s może } \\
\text { wskazywać na podwyższone } \\
\text { ryzyko krwawień }\end{array}$ & Nieużyteczny & Nieużyteczny & Nieużyteczny \\
\hline $\begin{array}{l}\text { Anty-FXa testy } \\
\text { chromogeniczne }\end{array}$ & Nieużyteczny & $\begin{array}{l}\text { Ocena ilościowa: brak } \\
\text { danych na temat wartości } \\
\text { odcięcia dla ryzyka krwa- } \\
\text { wienia lub zwiększonej } \\
\text { krzepliwości } \\
\text { Zakres wartości po osią- } \\
\text { gnięciu stabilnego stęże- } \\
\text { nia w surowicy (trough } \\
\text { level): 1,4-4,8 jm./ml }\end{array}$ & $\begin{array}{l}\text { Ocena ilościowa: brak } \\
\text { danych na temat wartości } \\
\text { odcięcia dla ryzyka krwa- } \\
\text { wienia lub zwiększonej } \\
\text { krzepliwości } \\
\text { Zakres wartości po osią- } \\
\text { gnięciu stabilnego stęże- } \\
\text { nia w surowicy (trough } \\
\text { level): 0,05-3,57 jm./ml }\end{array}$ & $\begin{array}{l}\text { Ocena ilościowa: brak } \\
\text { danych na temat wartości } \\
\text { odcięcia dla ryzyka krwa- } \\
\text { wienia lub zwiększonej } \\
\text { krzepliwości } \\
\text { Zakres wartości po osią- } \\
\text { gnięciu stabilnego stężenia } \\
\text { w surowicy (trough level): } \\
6-239 \mu \mathrm{g} / \mathrm{l}\end{array}$ \\
\hline ECT & $\begin{array}{l}\text { Zakres norm (10-90 P) po } \\
\text { osiągnięciu stabilnego stężenia } \\
\text { w surowicy: } \\
\text { - } 150 \mathrm{mg}-44,3-103 \mathrm{~s} \\
-110 \mathrm{mg}-40,4-84,6 \mathrm{~s} \\
\text { Wydłużenie ECT po osiągnięciu } \\
\text { stabilnego stężenia w osoc- } \\
\text { zu: } \geq 3 \times \text { X ULN może wskazywać } \\
\text { na wzrost ryzyka krwawień }\end{array}$ & Bez wpływu leku & Bez wpływu leku & Bez wpływu leku \\
\hline ACT & $\begin{array}{l}\text { Ograniczone zmiany parametru } \\
\text { w odpowiedzi na lek; nie ma } \\
\text { badań nad jego użytecznością; } \\
\text { ograniczona przydatność }\end{array}$ & $\begin{array}{l}\text { Brak danych; nie może } \\
\text { być stosowany }\end{array}$ & $\begin{array}{l}\text { Brak danych; nie może } \\
\text { być stosowany }\end{array}$ & $\begin{array}{l}\text { Minimalny wpływ leku; } \\
\text { nie może być stosowany }\end{array}$ \\
\hline
\end{tabular}

INR — międzynarodowy współczynnik znormalizowany; aPTT — czas kaolinowo-kefalinowy; dTT — czas trombinowy w rozcieńczonym osoczu; ECT — ekarynowy czas krzepnięcia; ACT — czas krzepnięcia po aktywacji; ULN — górna granica normy; FXa — czynnik krzepnięcia Xa 
Tabela 4. Wchłanianie i metabolizm nowych doustnych antykoagulantów [12-17]

\begin{tabular}{|c|c|c|c|c|}
\hline & Dabigatran & Apiksaban & Edoksaban & Riwaroksaban \\
\hline Biodostępność & $3-7 \%$ & $50 \%$ & $62 \%$ & $\begin{array}{l}\text { 66\% bez pokarmu; } \\
\text { ok. } 100 \% \text { przy przyjęciu } \\
\text { z pokarmem }\end{array}$ \\
\hline Prolek & Tak & Nie & $\mathrm{Nie}$ & Nie \\
\hline $\begin{array}{l}\text { Klirens pozanerkowy/nerkowy w pro- } \\
\text { centach przyjętej dawki (przy zacho- } \\
\text { wanej prawidłowej funkcji nerek) }\end{array}$ & $20 \% / 80 \%$ & $73 \% / 27 \%$ & $50 \% / 50 \%$ & $65 \% / 35 \%$ \\
\hline $\begin{array}{l}\text { Metabolizm w wątrobie: } \\
\text { z wykorzystaniem CYP3A4 }\end{array}$ & Nie & $\begin{array}{l}\text { Tak (eliminacja; } \\
\text { umiarkowany } \\
\text { udział CYP3A4) }\end{array}$ & $\begin{array}{c}\text { Minimalna } \\
(<4 \% \text { przyjętej dawki) }\end{array}$ & $\begin{array}{l}\text { Tak (eliminacja; } \\
\text { umiarkowany udział } \\
\text { CYP3A4) }\end{array}$ \\
\hline $\begin{array}{l}\text { Wchłanianie w zależności od } \\
\text { przyjmowanych pokarmów }\end{array}$ & Bez wpływu & Bez wpływu & $\begin{array}{c}\text { O 6-22\% lepsze } \\
\text { wchłanianie; minimalny } \\
\text { wpływ na całkowite } \\
\text { działanie leku }\end{array}$ & $\begin{array}{l}\text { O 39\% lepsze } \\
\text { wchłanianie }\end{array}$ \\
\hline $\begin{array}{l}\text { Wskazane przyjmowanie } \\
\text { z pokarmem? }\end{array}$ & Nie & $\mathrm{Nie}$ & Nie & Obowiązkowe \\
\hline $\begin{array}{l}\text { Wchłanianie w zależności od } \\
\text { przyjmowania antagonistów H2 } \\
\text { i inhibitorów pompy protonowej }\end{array}$ & $\begin{array}{l}\text { Od }-12 \% \text { do }-30 \% \\
\text { (bez istotności } \\
\text { klinicznej) }\end{array}$ & Bez wpływu & Bez wpływu & Bez wpływu \\
\hline Działanie u pacjentów rasy żółtej & $+25 \%$ & Bez wpływu & Bez wpływu & Bez wpływu \\
\hline $\begin{array}{l}\text { Działania niepożądane ze strony } \\
\text { przewodu pokarmowego }\end{array}$ & Dyspepsja u 5-10\% & Nie & Nie & Nie \\
\hline Czas połowicznej eliminacji & $12-17 \mathrm{~h}$ & $12 \mathrm{~h}$ & $10-14 \mathrm{~h}$ & $\begin{array}{l}\text { 5-9 h u osób młodych } \\
\text { 11-13 h u osób } \\
\text { starszych }\end{array}$ \\
\hline
\end{tabular}

i może prowadzić do decyzji o nieprzepisywaniu leku (kolor czerwony) lub dostosowania jego dawki (kolor pomarańczowy).

Niestety, w przypadku wielu leków powszechnie stosowanych u pacjentów z AF informacje na temat potencjalnych interakcji nie są jeszcze dostępne. W pewnych przypadkach zasadne może być powstrzymanie się od przepisywania NOAC do momentu uzyskania dodatkowych danych dotyczących interakcji. Obecnie na „liście czerwonej” dla dabigatranu znajdują się m.in.: dronedaron, ketokonazol, rifampicina, fenytoina, karbamazepina, cyklosporyna, takrolimus, fenobarbital. Na „liście pomarańczowej” jest werapamil, a na „liście żółtej”: amiodaron, chinidyna, klarytromicyna i erytromicyna. Ponadto czynnikami dodanymi w przypadku "listy żółtej” dla wszystkich leków są: podeszły wiek, niska masa ciała i zaburzenia funkcji nerek oraz inne czynniki zwiększające ryzyko krwawień. W przypadku apiksabanu na „liście pomarańczowej" znalazły się: ketokonazol, rifampicina, fenytoina, karbamazepina i fenobarbital, a na „liście żółtej” — diltiazem. Riwaroksaban wykazuje interakcje z ketokonazolem i inhibitorami proteazy HIV znajdującymi się na "liście czerwonej” oraz chinidyną, flukonazolem, cyklosporyną, klarytromicyną, erytromycyną, rifampiciną, fenytoiną, karbamazepiną i fe- nobarbitalem z "listy żółtej” [1]. Szczegółową listę znanych obecnie interakcji można również znaleźć pod adresem: http://www.NOACforAF.eu.

\section{Jak zmieniać schematy leczenia przeciwzakrzepowego?}

Podczas zmiany z jednego rodzaju terapii przeciwzakrzepowej na inny, istotna jest zarówno stała ochrona pacjenta przed incydentami zakrzepowymi, jak i nienarażanie go na nadmierne ryzyko krwawienia. Wymaga to poznania zasad takiego działania oraz ich stosowania na podstawie znajomości farmakokinetyki i farmakodynamiki poszczególnych leków.

Zmiana z VKA na NOAC. $U$ pacjentów przyjmujących dotychczas VKA leczenie przy użyciu NOAC może być rozpoczęte niezwłocznie (lub korzystniej kolejnego dnia), jeśli wartość międzynarodowego wskaźnika znormalizowanego (INR) jest niższa niż 2,0. Jeśli INR przekracza 2,5, na podstawie czasu półtrwania VKA (8-14 h dla acenokumarolu i 36-42 h dla warfaryny) trzeba oszacować, kiedy INR spadnie poniżej tej wartości i wtedy zlecić kolejny pomiar INR. Wówczas należy zaplanować następne oznaczenie INR. Na rycinie 2 przedstawiono schemat, który ma za zadanie połączyć różne dane z informacji dostępnych w ChPL, mó- 


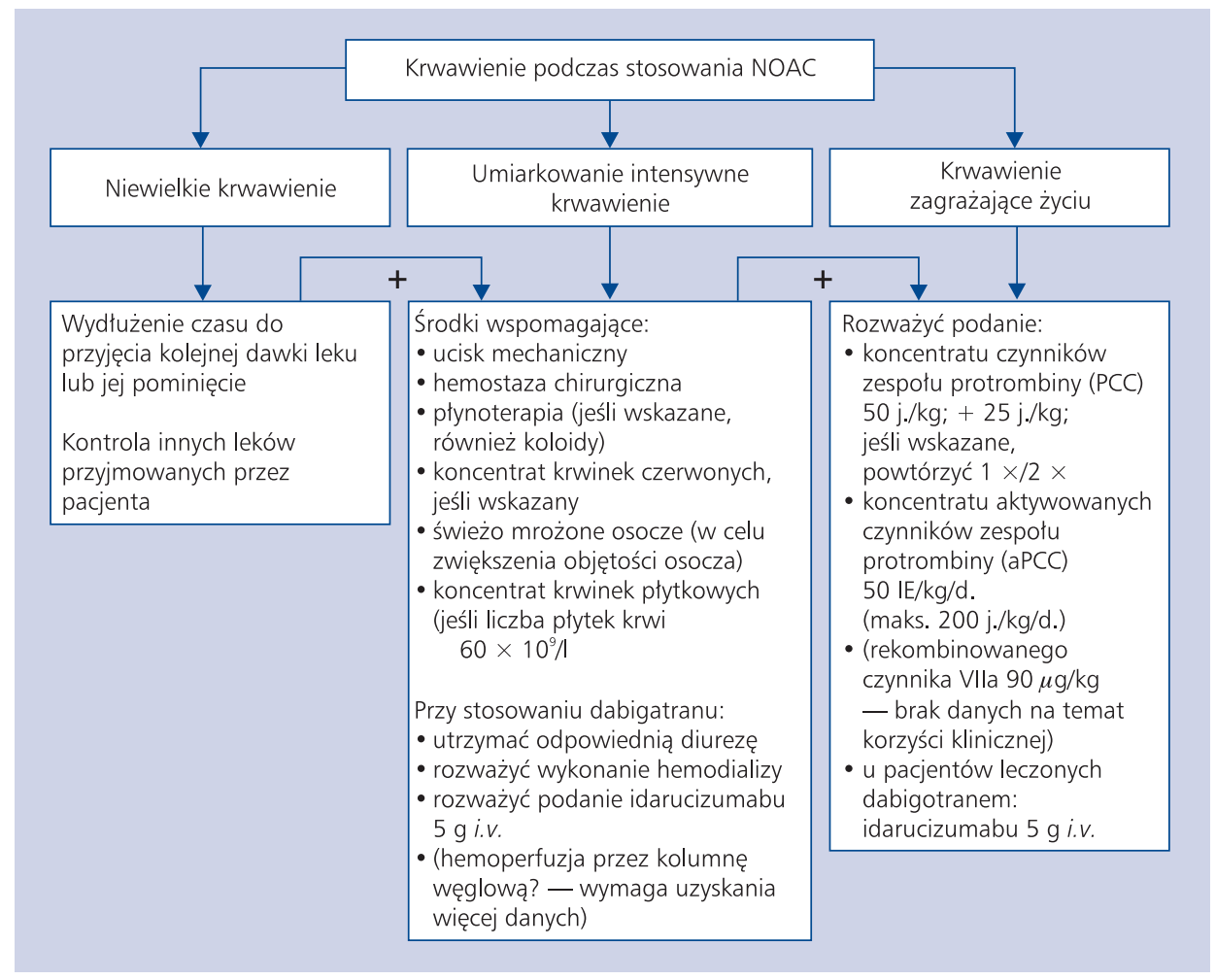

Rycina 2. Postępowanie w przypadku niewielkiego lub poważnego krwawienia u pacjentów przyjmujących doustne antykoagulanty niebędące antagonistami witaminy K (NOAC) [8]

wiące, że NOAC powinien być zastosowany przy INR $\leq 3$ dla riwaroksabanu, $\leq 2,5$ dla edoksabanu oraz $\leq 2$ dla apiksabanu i dabigatranu.

Zmiana z pozajelitowych środków przeciwzakrzepowych na NOAC. $U$ pacjentów, u których stosowano dożylną heparynę niefrakcjonowaną, włączenie NOAC może nastąpić w momencie przerwania podawania heparyn (czas półtrwania \pm 2 h). Ostrożność powinna być zachowana u pacjentów z przewlekłą chorobą nerek, ponieważ w ich przypadku czas eliminacji heparyny może być wydłużony. W przypadku heparyny drobnocząsteczkowej (LMWH) pierwszą dawkę NOAC podaje się w momencie, kiedy przewidziano zastosowanie kolejnej dawki LMWH.

Zmiana z NOAC na VKA. Ze względu na powolny początek działania VKA do momentu uzyskania INR w zakresie terapeutycznym może upłynąć 5-10 dni, w zależności od dużej zmienności osobniczej. W związku z tym NOAC i VKA powinny być podawane jednocześnie, aż do osiągnięcia pożądanej wartości INR; podobnie jak w przypadku równoczesnego stosowania LMWH podczas inicjacji VKA (ryc. 2). Dawka nasycająca nie jest zalecana dla acenokumarolu i warfaryny, ale jest zasadna w przypadku fenoprokumonu.

Nowe doustne antykoagulanty mogą dodatkowo działać na INR (zwłaszcza inhibitory czynnika Xa), wpływając na pomiar podczas jednoczesnego stosowania NOAC i VKA, dlatego też istotne jest, aby INR było mierzone tuż przed kolejną dawką NOAC oraz było ponownie zbadane po 24 h po ostatniej dawce NOAC (tj. już podczas wyłącznej terapii VKA) w celu zapewnienia odpowiedniego działania przeciwzakrzepowego. Zaleca się również, aby ściśle monitorować INR w ciągu pierwszego miesiąca, aż zostaną osiągnięte stabilne wartości (czyli trzy kolejne pomiary wynoszące 2,0-3,0). Pod koniec badania ENGAGE-AF pacjenci, u których leczenie zmieniano z edoksabanu na VKA, otrzymywali przez $<14$ dni połowę dawki NOAC, aż do osiągnięcia terapeutycznej wartości INR, przy jednoczesnym bardzo częstym monitorowaniu tego parametru [13].

Schemat zaproponowany powyżej okazał się korzystny, podczas gdy nieprawidłowo przeprowadzona zmiana jednego typu leczenia na drugi może się wiązać ze wzrostem ryzyka udaru mózgu. Nie ma danych dotyczących terapii pomostowej za pomocą połowy standardowej dawki NOAC.

Zmiana z NOAC na antykoagulant pozajelitowy. Włączenie LMWH lub heparyny niefrakcjonowanej może nastąpić wówczas, gdy podana miała być kolejna dawka NOAC.

Zmiana z NOAC na inny NOAC. Zamiana między preparatami z grupy NOAC może się odbywać w momencie, gdy powinna zostać przyjęta kolejna dawka pierwszego stosowanego preparatu, poza sytuacjami, kiedy przewidywane jest występowanie podwyższonych stężeń NOAC 
w surowicy (np. u pacjentów z zaburzeniami funkcji nerek). W takich sytuacjach odstęp pomiędzy dawkami powinien zostać wydłużony.

Zmiana z kwasu acetylosalicylowego (ASA) lub klopidogrelu na NOAC. NOAC mogą być zastosowane natychmiast, a przyjmowanie ASA lub klopidogrelu przerwane, o ile leczenie skojarzone nie zostanie uznane za konieczne pomimo zwiększonego ryzyka krwawienia (patrz niżej).

\section{Jak sobie radzić z błędami w dawkowaniu NOAC?}

Pytania dotyczące błędów w dawkowaniu NOAC są bardzo powszechne w codziennej praktyce klinicznej. Dość często pacjenci pytają o nie w szpitalach, przychodniach, a nawet centrach toksykologicznych. Wskazane jest, aby personel tych placówek posiadł jasne instrukcje, co doradzać pacjentom w takich przypadkach. Aby zapobiec sytuacjom opisanym powyżej, chorzy leczeni za pomocą NOAC powinni być zachęcani np. do korzystania z dobrze oznakowanych tygodniowych pojemników na tabletki z oddzielnymi przegródkami dla poszczególnych terminów dawkowania. Warto jednak podkreślić, że dabigatran nie może być wyjmowany z oryginalnego opakowania na czas znacznie przekraczający moment przyjęcia.

Ominięcie dawki leku. Pominięta dawka może być przyjęta, jeśli od planowanego czasu przyjęcia nie upłynęło więcej niż 50\% czasu, jaki zwykle dzieli dawki. Dlatego w przypadku NOAC dawkowanych dwa razy na dobę (co 12 h) pacjent może przyjąć pominiętą dawkę do $6 \mathrm{~h}$ od zaplanowanej pory zastosowania. U osób z wysokim ryzykiem udaru mózgu i niskim ryzykiem krwawienia czas ten może być przedłużony aż do momentu przyjęcia następnej zaplanowanej dawki. W przypadku NOAC ze schematem dawkowania raz na dobę pacjent może przyjąć pominiętą dawkę aż do $12 \mathrm{~h}$ po planowanym czasie. Jeśli nie jest to już możliwe, dawka powinna być pominięta, a leczenie wznowione od następnej zaplanowanej dawki.

Przyjęcie podwójnej dawki leku. Jeśli pacjent przypadkowo zażyje podwójną dawkę leku w przypadku preparatów dawkowanych dwa razy na dobę można pominąc kolejną dawkę, a lek przyjąć ponownie po upływie 24 h od przyjęcia podwójnej dawki. W przypadku preparatów dawkowanych raz na dobę nie zaleca się omijania dawki, a lek należy dalej przyjmować o ustalonej porze.

Niepewność dotycząca przyjęcia dawki leku. Zdarza się, że pacjent nie jest pewny, czy dawka leku została przyjęta, czy jednak nie. W przypadku NOAC ze schematem dawkowania dwa razy na dobę można zalecić, aby chory nie brał kolejnej tabletki, ale po prostu kontynuował zaplanowany schemat dawkowania, co oznacza przyjęcie następnej dawki w ciągu 12 h. W przypadku NOAC ze schematem dawkowania raz na dobę, jeśli ryzyko krwawienia jest niskie (HAS-BLED $\leq 2)$ lub ryzyko zakrzepowo-zatorowe jest wysokie $\left(\mathrm{CHA}_{2} \mathrm{DS}_{2}\right.$ -VASc $\geq 3$ ), można doradzić, aby przyjąć kolejną tabletkę, a następnie kontynuować zaplanowany schemat dawkowania. W przypadku, gdy ryzyko krwawienia jest wysokie (HAS-BLED $\geq 3$ ) lub ryzyko zakrzepowo-zatorowe jest niskie $\left(\mathrm{CHA}_{2} \mathrm{DS}_{2}\right.$-VASc $\left.\leq 2\right)$, można doradzić, aby pacjent poczekał do następnej zaplanowanej dawki.

Przedawkowanie NOAC. W zależności od podejrzewanej ilości przedawkowanych leków może być wskazana hospitalizacja w celu monitorowania pacjenta. Zagadnienie to omówiono w dalszej części artykułu.

\section{SPECYFICZNE GRUPY CHORYCH Pacjenci z przewlekłą chorobq̨ nerek}

U pacjentów z przewlekłą chorobą nerek (CKD) i AF istnieje zwiększone ryzyko zarówno powikłań zakrzepowo-zatorowych, jak i krwawienia. Coraz częściej mówi się również o wpływie CKD na strategię postępowania w arytmii [14]. Potwierdzono to w badaniach dotyczących NOAC oraz w długoterminowych rejestrach. Najnowsze odkrycia sugerują, że klirens kreatyniny $(\mathrm{CrCl})<60 \mathrm{ml} /$ min może być nawet niezależnym predyktorem wystąpienia udaru mózgu i zatorowości obwodowej $[15,16]$. Niektóre dane wskazują, że doustne leczenie przeciwzakrzepowe wiąże się z większymi względnymi korzyściami u pacjentów z łagodną lub umiarkowaną CKD w porównaniu z osobami z prawidłową funkcją nerek [17, 18].

Wszystkie NOAC są częściowo wydalane przez nerki. Ocena czynności nerek jest zatem ważna w celu oszacowania ich klirensu w organizmie (tab. 4). W kontekście leczenia NOAC, klirens kreatyniny najlepiej oszacować metodą Cockcrofta-Gaulta, ponieważ zastosowano ją w większości badań dotyczących NOAC. Formuła zawiera wiek, masę ciała oraz płeć i pozwala określić $\mathrm{CrCl}$ w zależności od stężenia kreatyniny w surowicy $-\mathrm{CrCl}=(140-$ wiek $) \times$ masa ciała $(\mathrm{kg}) \times(0,85$, jeśli kobieta $) / 72 \times$ stężenie kreatyniny w surowicy $(\mathrm{mg} / \mathrm{dl})$. Należy zachęcać lekarzy do używania kalkulatorów $\mathrm{CrCl}$ dostępnych na stronach internetowych lub w aplikacjach mobilnych.

Wielu pacjentów z łagodną lub umiarkowaną CKD (tj. $\mathrm{CrCl}$ 30-89 ml/min) zostało włączonych do badań dotyczących NOAC. $U$ chorych z $\mathrm{CrCl}$ 30-49 ml/min dabigatran w dawce 150 mg dwa razy na dobę może być przepisywany zgodnie z ChPL, ale w wytycznych ESC zaleca się zastosowanie dawki 110 mg dwa razy na dobę [9].

Riwaroksaban, apiksaban i edoksaban są również dopuszczone w Europie do stosowania u pacjentów w 4. stadium CKD (tj. CrCl 15-30 ml/min) w obniżonych dawkach. Jednak nie ma informacji dotyczących skuteczności i bezpieczeństwa poszczególnych NOAC u pacjentów z zaawansowaną $\mathrm{CKD}(\mathrm{CrCl}<30 \mathrm{ml} / \mathrm{min})$, a w aktualnych wytycznych ESC nie zaleca się ich stosowania w tej grupie chorych (tab. 4).

Wskazówki praktyczne. W tabeli 5 przedstawiono czas półtrwania poszczególnych substancji w zależności od $\mathrm{CrCl}$ pacjenta, a w tabeli 6 zawarto, m.in. zależny od funkcji nerek, 
Tabela 5. Szacowany czas półtrwania nowych doustnych antykoagulantów u pacjentów w różnym stadium zaawansowania przewlekłej choroby nerek (CKD) w porównaniu z osobami zdrowymi [23, 24]

\begin{tabular}{|c|c|c|c|c|}
\hline & Dabigatran & Apiksaban & Edoksaban & Riwaroksaban \\
\hline Klirens kreatyniny $>80 \mathrm{ml} / \mathrm{min}$ & $12-17 \mathrm{~h}$ & $12 \mathrm{~h}$ & $10-14 \mathrm{~h}$ & $\begin{array}{l}\text { 5-9 h u osób młodych } \\
\text { 11-13 h u osób starszych }\end{array}$ \\
\hline $\begin{array}{l}\text { Klirens kreatyniny } 50-80 \mathrm{ml} / \mathrm{min} \\
\text { CKD I-II stadium }\end{array}$ & $\sim 17 \mathrm{~h}(+50 \%)$ & $\sim 14,6 \mathrm{~h}(+16 \%)$ & $\sim 8,6 \mathrm{~h}(+32 \%)$ & $\sim 8,7 \mathrm{~h}(+44 \%)$ \\
\hline $\begin{array}{l}\text { Klirens kreatyniny } 30-50 \mathrm{ml} / \mathrm{min} \\
\text { CKD III stadium }\end{array}$ & $\sim 19 \mathrm{~h}(+320 \%)$ & $\sim 17,6 \mathrm{~h}(+29 \%)$ & $\sim 9,4 \mathrm{~h}(+74 \%)$ & $\sim 9 \mathrm{~h}(+52 \%)$ \\
\hline $\begin{array}{l}\text { Klirens kreatyniny } 15-30 \mathrm{ml} / \mathrm{min} \\
\text { CKD IV stadium }\end{array}$ & $\sim 28 \mathrm{~h}(+530 \%)$ & $\sim 17,3 \mathrm{~h}(+44 \%)$ & $\sim 16,9$ h $(+72 \%)$ & $\sim 9,5 \mathrm{~h}(+64 \%)$ \\
\hline $\begin{array}{l}\text { Klirens kreatyniny } \leq 15 \mathrm{ml} / \mathrm{min} \\
\text { CKD V stadium, bez dializ }\end{array}$ & Brak danych & $-(+36 \%)$ & $-(+93 \%)$ & $-(+70 \%)$ \\
\hline
\end{tabular}

Tabela 6. Nowe doustne antykoagulanty u pacjentów z niewydolnością nerek — zatwierdzone europejskie wskazania i dawkowanie w przypadku przewlekłej choroby nerek (CKD)

\begin{tabular}{|c|c|c|c|c|}
\hline & Dabigatran & Apiksaban & Edoksaban & Riwaroksaban \\
\hline $\begin{array}{l}\text { Procent wchłoniętej dawki } \\
\text { wydalany przez nerki }\end{array}$ & $80 \%$ & $27 \%$ & $50 \%$ & $35 \%$ \\
\hline Biodostępność & $3-7 \%$ & $50 \%$ & $62 \%$ & $\begin{array}{c}\text { 66\% bez pokarmu } \\
\text { (ok. } 100 \% \text { przy przyjęciu } \\
\text { z pokarmem) }\end{array}$ \\
\hline $\begin{array}{l}\text { Procent przyjętej dawki } \\
\text { wydalany przez nerki }\end{array}$ & $4 \%$ & $12-29 \%$ & $37 \%$ & $33 \%$ \\
\hline $\begin{array}{l}\text { Zarejestrowany przy } \\
\text { klirensie kreatyniny }\end{array}$ & $\geq 30 \mathrm{ml} / \mathrm{min}$ & $\geq 15 \mathrm{ml} / \mathrm{min}$ & $\geq 15 \mathrm{ml} / \mathrm{min}$ & $\geq 15 \mathrm{ml} / \mathrm{min}$ \\
\hline $\begin{array}{l}\text { Zalecenia dotyczące } \\
\text { dawkowania }\end{array}$ & $\begin{array}{l}\text { Przy klirensie kreatyni- } \\
\text { ny } \geq 50 \mathrm{ml} / \mathrm{min} \text { : bez } \\
\text { zmian dawkowania }\end{array}$ & $\begin{array}{l}\text { Przy stężeniu kreatyniny } \\
\text { w osoczu } \geq 1,5 \mathrm{mg} / \mathrm{dl} \text { : } \\
\text { bez zmian dawkowania }\end{array}$ & $\begin{array}{l}\text { Przy klirensie kreatyni- } \\
\text { ny } \geq 50 \mathrm{ml} / \mathrm{min} \text { : bez } \\
\text { zmian dawkowania }\end{array}$ & $\begin{array}{l}\text { Przy klirensie kreatyni- } \\
\text { ny } \geq 50 \mathrm{ml} / \mathrm{min} \text { : bez } \\
\text { zmian dawkowania }\end{array}$ \\
\hline $\begin{array}{l}\text { Dawkowanie } \\
\text { w przypadku CKD }\end{array}$ & $\begin{array}{l}\text { Przy klirensie kreatyniny } \\
30-49 \mathrm{ml} / \mathrm{min} \text { : dawka } \\
150 \mathrm{mg} \text { bid, ale należy } \\
\text { rozważyć } 110 \mathrm{mg} \text { bid }\end{array}$ & $\begin{array}{c}\text { Przy klirensie kreatyniny } \\
15-29 \text { ml/min: dawka } \\
2,5 \text { mg bid } \\
\text { Jeśli stężenie kreatyniny } \\
\text { w osoczu } \geq 1,5 \text { mg/dl } \\
\text { w dwóch z trzech po- } \\
\text { miarów, wiek } \geq 80 \text { lat, } \\
\text { masa ciała } \leq 60 \text { kg: } \\
2,5 \text { mg bid }\end{array}$ & $\begin{array}{l}30 \text { mg qd, jeśli klirens } \\
\text { kreatyniny 15-49 ml/min }\end{array}$ & $\begin{array}{l}15 \text { mg qd, jeśli klirens } \\
\text { kreatyniny } 15-49 \mathrm{ml} / \mathrm{min}\end{array}$ \\
\hline $\begin{array}{l}\text { Niezalecany, gdy klirens } \\
\text { kreatyniny }\end{array}$ & $<30 \mathrm{ml} / \mathrm{min}$ & $<15 \mathrm{ml} / \mathrm{min}$ & $<15 \mathrm{ml} / \mathrm{min}$ & $<15 \mathrm{ml} / \mathrm{min}$ \\
\hline
\end{tabular}

bid (łac. bis in die) — dwa razy na dobę; qd (łac. quaque die) — raz na dobę

Dawka powinna być zredukowana także w przypadku występowania innych czynników ryzyka i/lub stosowania leków zmieniających metabolizm doustnych antykoagulantów niebędących antagonistami witaminy K (patrz tekst)

sposób zmiany dawkowania NOAC. Obecnie odradza się podawanie NOAC chorym, u których $\mathrm{CrCl}$ wynosi mniej niż $30 \mathrm{ml} / \mathrm{min}$, a tym bardziej mniej niż $15 \mathrm{ml} / \mathrm{min}$, ze względu na znikomą liczbę danych dotyczących tej grupy pacjentów [2]. Zalecenia dotyczące stosowania NOAC u pacjentów z CKD można podsumować następująco:
- CKD powinna być traktowana jako czynnik ryzyka udaru mózgu u pacjentów z AF;

- NOAC wykazują podobny bilans korzyści do ryzyka jak VKA u pacjentów z CKD;

- obecnie nie istnieją badania porównujące skuteczność różnych NOAC u osób z CKD; 
— z powodu braku dowodów naukowych uzasadniających stosowanie NOAC u pacjentów z CKD poddawanym dializom lub w przedschyłkowym stadium choroby, obecnie $w$ tej grupie preferowane jest unikanie stosowania NOAC;

- monitorowanie funkcji nerek jest konieczne w celu ustalenia prawidłowego dawkowania i bezpieczeństwa terapii NOAC; częstość monitorowania funkcji nerek można ustalić na podstawie wzoru (liczba miesięcy $=\mathrm{CrCl} / 10$ ) (tab. 5 i 6 , ryc. 1 i 2 ).

\section{Postępowanie w przypadku (podejrzewanego) przedawkowania NOAC, bez krwawienia lub koagulologicznych wykładników podwyższonego ryzyka krwawień}

Dawki NOAC przekraczające te zalecane mogą narazić pacjenta na zwiększone ryzyko krwawienia. Taka sytuacja może wystąpić, gdy chory (celowo) przyjmie nadmierną dawkę lub występują schorzenia współistniejące (takie jak ostra niewydolność nerek, zwłaszcza przy podawaniu dabigatranu; stosowanie leków mogących wchodzić w interakcje farmakokinetyczne z NOAC), które mogą powodować podwyższone stężenie NOAC w osoczu przekraczające poziomy terapeutyczne. W odniesieniu do planowania leczenia ważne jest rozróżnienie między przedawkowaniem z komplikacjami krwotocznymi i bez nich (w przypadku powikłań krwotocznych - patrz niżej).

W przypadku niedawnego (świeżego) przyjęcia nadmiernej dawki NOAC (zwłaszcza $\leq 2$ h) wykorzystanie węgla aktywowanego w celu zmniejszenia absorpcji można zastosować dla każdego NOAC (ze standardowym schematem dawkowania dla dorosłych 30-50 g), chociaż brakuje danych klinicznych na temat jego skuteczności $[19,20]$.

W przypadku podejrzenia przedawkowania testy krzepnięcia mogą pozwolić na określenie jego stopnia i ewentualnego ryzyka krwawienia (patrz wyżej). Ze względu na stosunkowo krótki okres półtrwania NOAC strategia "czujnego obserwowania" może być zalecana w większości przypadków bez aktywnego krwawienia. Jeśli jest konieczna bardziej intensywna normalizacja stężenia w osoczu lub nie jest spodziewana szybka normalizacja (np. w CKD), mogą zostać podjęte kroki opisane poniżej — w częściach dotyczących leczenia krwawień, w tym stosowanie niespecyficznych czynników odwracających działanie leków.

\section{Postępowanie w przypadku powikłań krwotocznych}

Wyniki badań trzeciej fazy dotyczących NOAC wykazały, że profil występowania krwawień przy stosowaniu NOAC jest korzystniejszy w stosunku do warfaryny, zwłaszcza w odniesieniu do krwawienia wewnątrzczaszkowego i innych krwawień zagrażających życiu. Ponadto rokowanie w przypadku wystąpienia krwawienia przy stosowaniu NOAC było kor- zystniejsze. Wykazano, że krwawienia były bardziej łagodne niż w przypadku leczenia za pomocą VKA [21, 22]. Również mniej krwawień w trakcie terapii NOAC doprowadziło do konieczności zmiany leczenia przeciwzakrzepowego, co powoduje również zmniejszenie wczesnej i późnej śmiertelności. Niemniej jednak, gdy więcej pacjentów będzie leczonych NOAC, można się spodziewać wzrostu bezwzględnej liczby krwawień spowodowanych NOAC.

Odwrócenie działania VKA poprzez zastosowanie witaminy K ma powolny początek (tj. co najmniej $24 \mathrm{~h}$ ). Podanie świeżo mrożonego osocza szybciej przywraca koagulację, ale jest mniej efektywne niż użycie koncentratów czynników kompleksu protrombiny (PCC) oceniane zarówno przez wartości INR, jak również wyniki oznaczeń czynników krzepnięcia zależnych od witaminy K. W przypadku NOAC jednak nadmiar leku w osoczu może blokować nowo podawane czynniki krzepnięcia. Dlatego też zastosowanie świeżo mrożonego osocza nie może być uważane za prawidłową strategię odwracania działania NOAC. Z kolei, jak omówiono poniżej, koncentraty czynników krzepnięcia mogą być stosowane do odwracania działania NOAC. Mimo że istnieje coraz więcej doniesień na temat krwawień u pacjentów leczonych NOAC w kontekście stosowania koncentratów protrombiny, to ciągle brakuje prospektywnych randomizowanych danych. W związku z tym zalecenia dotyczące postępowania w przypadku krwawienia nadal opiera się głównie na wynikach badań przedklinicznych i opinii ekspertów. Specyficzny czynnik odwracający działanie dabigatranu (idarucizumab — fragment przeciwciała humanizowanego, który specyficznie wiąże dabigatran) zyskał już rejestrację w Europie, po publikacji wyników badania REVERSE-AD, które wykazały niemal całkowite odwrócenie skutków antykoagulacyjnych dabigatranu w ciągu kilku minut [24]. U zdrowych ochotników idarucizumab spowodował natychmiastowe i całkowite odwrócenie efektu przeciwzakrzepowego dabigatranu, bez zwiększania stężeń biomarkerów prokoagulacyjnych [25]. Ponadto po $24 \mathrm{~h}$ od zastosowania idarucizumabu podanie dabigatranu pozwalało na przywrócenie prawidłowej farmakokinetyki leku z zachowaniem maksymalnego i minimalnego stężenia w osoczu [24-26]. Jeżeli idarucizumab nie byłby łatwo dostępny podczas komplikacji krwotocznych dabigatranu lub w przypadku wystąpienia krwawienia u pacjenta leczonego dowolnym inhibitorem czynnika Xa, można odwołać się do niespecyficznych strategii leczenia, które omówiono poniżej.

Krwawienia niezagrażające życiu. Oprócz standardowych środków pomocniczych (takich jak ucisk mechaniczny, hemostaza chirurgiczna, uzupełnianie płynów i innych środków podtrzymujących równowagę hemodynamiczną), w związku ze stosunkowo krótkim okresem półtrwania, czas stanowi najważniejsze antidotum na działanie NOAC (ryc. 3). Po zaprzestaniu leczenia przywrócenia hemostazy należy się spodziewać w ciągu 12-24 h po przyjęciu ostatniej dawki leku, ponieważ okres półtrwania dla większości NOAC 


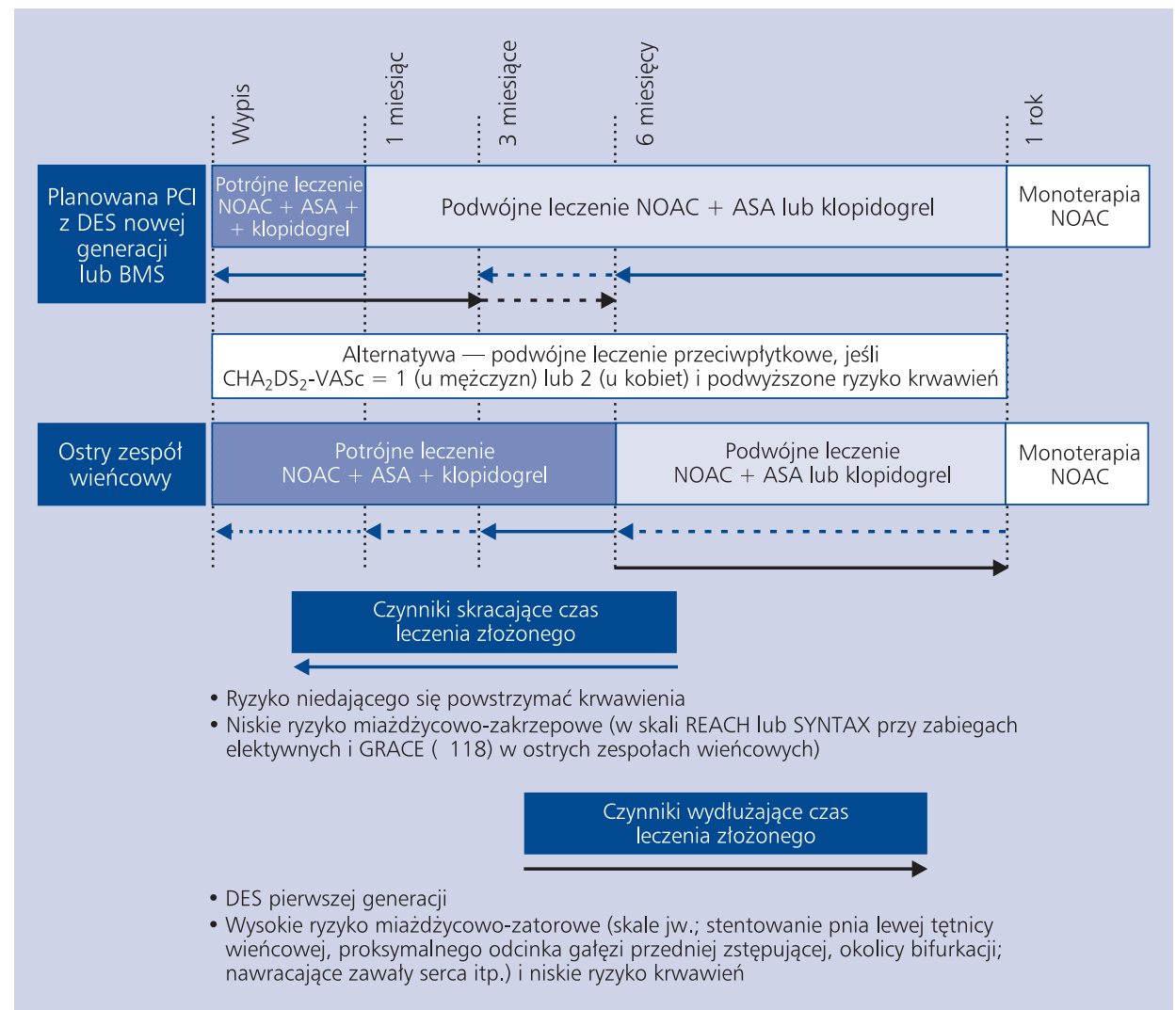

Rycina 3. Możliwe scenariusze włączenia i długoterminowego stosowania doustnych antykoagulantów niebędących antagonistami witaminy K (NOAC) u pacjentów po rewaskularyzacji lub ostrym zespole wieńcowym. Leczenie powinno być modyfikowane z zależności od charakterystyki pacjenta i praktyki klinicznej w danym ośrodku (patrz tekst); kwas acetylosalicylowy (ASA) 75-100 mg raz na dobę; klopidogrel — 75 mg raz na dobę; BMS — stent metalowy; DES — stent uwalniający lek; PCI — przezskórna interwencja wieńcowa

wynosi ok. 12 h [27]. Pacjentów trzeba pytać o przepisany schemat dawkowania, dokładny czas od przyjęcia ostatniej dawki, czynniki wpływające na stężenie w osoczu (takie jak terapia lekami wykazującymi interakcję z P-gp, CKD) oraz inne sytuacje kliniczne modyfikujące hemostazę (takie jak równoczesne stosowanie leków przeciwpłytkowych). Powinno się uwzględnić uzupełnienie objętości krwi i przywrócenie prawidłowej liczby płytek krwi (w przypadku małopłytkowości $\leq 60 \times 10^{9} /$ l lub trombopatii).

Krwawienia zagrażające życiu. U pacjentów otrzymujących dabigatran podanie idarucizumabu, o ile jest dostępny, jest korzystnym czynnikiem odwracającym działanie leku. Badanie pilotażowe nie zostało zaprojektowane, aby porównać rokowanie, ale badacze zaobserwowali przywrócenie hemostazy u większości pacjentów z poważnym krwawieniem lub wymagających pilnej operacji po podaniu idarucizumabu [24]. Zaleca się konsultację pomiędzy kardiologami, ekspertami do spraw hemostazy i lekarzami medycyny ratunkowej w celu opracowania polityki szpitalnej w procesie postępowania w przypadku krwawienia. Zasady te powinny być właściwie przekazane i być łatwo dostępne (np. na stronie internetowej lub w postaci kieszonkowych ulotek).

\section{Pacjenci poddawani planowym interwencjom chirurgicznym lub ablacji}

Kiedy przerwać leczenie NOAC? Zabiegi chirurgiczne lub procedury inwazyjne, które wiążą się z ryzykiem krwawienia, wymagają czasowego przerwania stosowania NOAC. Badania wykazały, że ok. 1/4 pacjentów leczonych przeciwzakrzepowo wymaga czasowego przerwania terapii w ciągu 2 lat [28]. Przy przerywaniu i ponownym stosowaniu leku powinno się brać pod uwagę zarówno cechy pacjenta (funkcja nerek, wiek, historia powikłań krwotocznych i jednocześnie przyjmowane leki), jak i czynniki chirurgiczne (tab. 7). Leczenie pomostowe za pomocą LMWH lub heparyny niefrakcjonowanej, tak jak zaproponowano u pacjentów z AF i podwyższonym ryzykiem powikłań zakrzepowo-zatorowych leczonych VKA, nie jest konieczne w przypadku osób leczonych NOAC, ponieważ przewidywany zanik efektu przeciwzakrzepowego pozwala na odpowiednio krótkoterminowe zaprzestanie i ponowne rozpoczęcie leczenia NOAC przed i po zabiegu [29, 30]. Ponadto wyniki badania BRIDGE także nie pokazały, że pacjenci terapia VKA, u których zastosowano leczenie pomostowe za pomocą LMWH, ma przewagę w zakresie redukcji ryzyka zakrzepowo-zatorowego, potwierdziły natomiast, że 
Tabela 7. Czas przyjęcia ostatniej dawki leku przed planową operacją chirurgiczną

\begin{tabular}{|c|c|c|c|c|}
\hline \multirow{3}{*}{$\begin{array}{l}\text { Klirens } \\
\text { kreatyniny } \\
\text { [ml/min] }\end{array}$} & \multicolumn{2}{|c|}{ Dabigatran } & \multicolumn{2}{|c|}{ Apiksaban } \\
\hline & \multicolumn{4}{|c|}{$\begin{array}{l}\text { Bez istotnego ryzyka krwawienia i/lub możliwa skuteczna miejscowa hemostaza: } \\
\text { wykonać w momencie osiągnięcia najmniejszego stężenia w osoczu (through level), } \\
\text { np. po } \geq 12-24 \text { h od ostatniej dawki }\end{array}$} \\
\hline & Niskie ryzyko & Wysokie ryzyko & Niskie ryzyko & Wysokie ryzyko \\
\hline$\geq 80$ & $\geq 24 \mathrm{~h}$ & $\geq 48 \mathrm{~h}$ & $\geq 24 \mathrm{~h}$ & $\geq 48 \mathrm{~h}$ \\
\hline $50-80$ & $\geq 36 \mathrm{~h}$ & $\geq 72 \mathrm{~h}$ & $\geq 24 \mathrm{~h}$ & $\geq 48 \mathrm{~h}$ \\
\hline $30-50$ & $\geq 48 \mathrm{~h}$ & $\geq 96 \mathrm{~h}$ & $\geq 24 \mathrm{~h}$ & $\geq 48 \mathrm{~h}$ \\
\hline $15-30$ & Nie zaleca się stosowania & Nie zaleca się stosowania & $\geq 36 \mathrm{~h}$ & $\geq 48 \mathrm{~h}$ \\
\hline$<30$ & \multicolumn{4}{|c|}{ Nie zaleca się stosowania } \\
\hline
\end{tabular}

Nie ma potrzeby stosowania terapii pomostowej z zastosowaniem heparyny niefrakcjonowanej lub niskocząsteczkowej.

Pogrubioną czcionką wyróżniono wartości stanowiące odstępstwo od reguły: $\geq 24$ h przy niskim ryzyku i $\geq 48$ h przy wysokim ryzyku; niskie ryzyko - operacja chirurgiczna związana z niskim ryzykiem krwawienia; wysokie ryzyko — operacja chirurgiczna związana z wysokim ryzykiem krwawienia

jest ona gorsza w kontekście ryzyka poważnych krwawień [31]. European Heart Rhythm Association i inne stowarzyszenia opracowały obszerne zalecenia na temat leczenia przeciwzakrzepowego u chorych poddawanych zabiegom elektrofizjologicznym, w tym tymczasowego zaprzestania terapii NOAC [32, 33]. Dane z rejestrów wykazały, że terapia pomostowa jest wciąż niewłaściwie stosowana u pacjentów leczonych NOAC, co prowadzi do znacznie wyższego okołozabiegowego ryzyka krwawienia (bez niższego ryzyka powikłań zakrzepowo-zatorowych) [30]. Również w omawianym dokumencie EHRA [4] ponownie zalecono opracowanie wytycznych właściwych dla danej instytucji szpitalnej w celu zarządzania leczeniem przeciwzakrzepowym w przypadku różnych zabiegów chirurgicznych.

Gdy interwencja wiąże się $z$,klinicznie istotnym ryzykiem krwawień" i/lub przy możliwej odpowiedniej lokalnej hemostazie, jak w przypadku niektórych zabiegów stomatologicznych lub zaćmy czy jaskry, zabieg może być wykonywany przy terapeutycznym stężeniu NOAC (czyli 12 h lub 24 h po ostatnim przyjęciu, w zależności od dawkowania raz lub dwa razy na dobę), ale nie powinien być on przeprowadzany przy stężeniu maksymalnym. Niemniej jednak, może być bardziej praktyczne, aby interwencję zaplanować 18-24 h po przyjęciu ostatniej dawki leku, a następnie włączyć go ponownie 6 h później, czyli omijając jedną dawkę NOAC stosowaną dwa razy na dobę. W takich przypadkach pacjent może opuścić klinikę jedynie wówczas, gdy krwawienie jest całkowicie zatrzymane i być poinstruowany o normalnym toku postępowania pooperacyjnego oraz środkach, jakie należy podjąć w przypadku wystąpienia krwawienia (tzn. skontaktować się z lekarzem lub stomatologiem w przypadku krwawienia, które nie kończy się spontanicznie). W przypadku procedur stomatologicznych po zabiegu pacjent może delikatnie płukać usta $10 \mathrm{ml}$ 5-procentowego kwasu traneksamowego cztery razy dziennie przez okres 5 dni.
W przypadku zabiegów z „niskim ryzykiem krwawienia” (tzn. z niską częstością krwawień i/lub niewielkim wpływem na krwawienia, zaleca się zastosować ostatnią dawkę NOAC $24 \mathrm{~h}$ przed elektywnym zabiegiem u pacjentów z prawidłową czynnością nerek (tab. 7). W przypadku zabiegów, które prowadzą do „zagrożenia poważnym krwawieniem” (czyli z dużą częstością krwawień i/lub istotnym wpływem klinicznym), zaleca się przyjąć ostatnią dawkę NOAC 48 h wcześniej. U pacjentów z CrCl 15-30 ml/min zaleca się rozważenie wcześniejszego niż 24-godzinnego przerwania stosowania każdego z inhibitorów czynnika Xa, zarówno w przypadku interwencji o niskim, jak i wysokim ryzyku krwawienia, czyli podanie ostatniej dawki leku odpowiednio $\geq 36 \mathrm{~h} \mathrm{i} \geq 48 \mathrm{~h}$ przed zabiegiem. Dla dabigatranu zaproponowano nieco inny schemat przerywania leczenia w zależności od czynności nerek, zarówno w przypadku interwencji o niskim, jak i wysokim ryzyku (tab. 7).

W przypadku procedur, takich jak znieczulenie podpajęczynówkowe, zewnątrzoponowe i punkcja lędźwiowa może być wymagana pełna hemostaza i są one zaliczane do kategorii „wysokiego ryzyka krwawienia”. Autorzy dokumentu EHRA nie zalecają tych typów znieczulenia w przypadku nieprzerwanego stosowania NOAC.

Chociaż czas koalinowo-kefalinowy (APTT) oraz czas protombinowy (PT) mogą dostarczyć półilościowej oceny dabigatranu i inhibitorów czynnika Xa, odpowiednio (patrz wyżej), to strategia, która obejmuje normalizację APTT lub PT przed elektywnymi/pilnymi interwencjami nie została zatwierdzona. Nie ma też takiej zbadanej strategii w przypadku bardziej szczegółowych badań krzepnięcia, takich jak czas trombinowy w rozcieńczonym osoczu lub testy chromogenne.

Kiedy wznowić leczenie NOAC? W przypadku elektywnych zabiegów z natychmiastową i całkowitą hemostazą przyjmowanie NOAC można wznowić $6-8 \mathrm{~h}$ po zabiegu. To samo odnosi się do nietraumatycznych znieczuleń zewnątrzo- 
ponowych i podpajęczynówkowych lub niepowikłanej punkcji lędźwiowej. W przypadku wielu interwencji chirurgicznych wznowienie pełnej dawki leków przeciwzakrzepowych w czasie pierwszych 48-72 h po zabiegu może się wiązać z ryzykiem krwawienia, które może przeważyć nad ryzykiem incydentów sercowo-zatorowych. Należy również wziąć pod uwagę brak specyficznego antidotum (oprócz dabigatranu) w sytuacji wystąpienia krwawienia i/lub potrzeby ponownej interwencji. W przypadku procedur związanych z unieruchomieniem uważa się za właściwe rozpoczęcie tromboprolifaktyki w zmniejszonej (np. 0,5 mg/kg/dzień enoksaparyny) lub pośredniej dawce LMWH (np. $1 \mathrm{mg} / \mathrm{kg} /$ dzień enoksaparyny) 6-8 h po operacji, jeżeli odpowiednia hemostaza została osiągnięta. Natomiast pełne terapeutyczne leczenie przeciwzakrzepowe poprzez ponowne włączanie NOAC powinno być odroczone do 48-72 h po zabiegu inwazyjnym.

\section{Pacjenci wymagajacy pilnych interwencji chirurgicznych}

Jeśli wymagana jest interwencja pilna, to stosowanie NOAC należy przerwać. Operacja lub interwencja powinna być odroczona, jeśli to możliwe, aż do co najmniej 12 h, a najlepiej $24 \mathrm{~h}$ po podaniu ostatniej dawki leku. Jeżeli operacja nie może być opóźniona, można wziąć pod uwagę odwrócenie działania antykoagulantu. Jak wspomniano, badania przeprowadzone wśród zdrowych ochotników wykazały, że PCC lub aktywowany PCC w sposób zależny od dawki mogą odwrócić skutki działania NOAC [34, 35]. Mimo ograniczonego doświadczenia w ich stosowaniu w chirurgii stanów nagłych zalecenia te nigdy nie zostały prospektywnie potwierdzone. W związku z niedawną rejestracją Europejskiej Agencji Leków (EMA) w tym wskazaniu można rozważyć podanie idarucizumabu u pacjentów leczonych dabigatranem [przyp. red.].

\section{Pacjenci z migotaniem przedsionków i chorobq wieńcowa}

Współwystępowanie AF i choroby wieńcowej (CAD) jest nie tylko częste w praktyce klinicznej, ale stanowi też złożone zagadnienie, które należy brać pod uwagę przy planowaniu leczenia przeciwzakrzepowego i przeciwpłytkowego, również dlatego, że wiąże się ono ze znacznie wyższymi wskaźnikami śmiertelności [36]. Niestety, nie ma wystarczających danych pozwalających na optymalnie prowadzenie praktyki klinicznej w takich przypadkach, co zostało usystematyzowane w innych niedawnych dokumentach sygnowanych przez ESC [37-39]. W dokumencie EHRA zalecenia zaczerpnięto z wyżej wymienionych wytycznych, z postawieniem szczególnego akcentu na terapię NOAC. Nie ma obecnie randomizowanych badań porównujących VKA i NOAC u chorych z AF poddawanych przezskórnym interwencjom wieńcowym (PCI) w ostrych zespołach wieńcowych (ACS) lub ze stabilną CAD, czyli chorych, u których istnieją wskazania do stosowania pojedynczej lub podwójnej terapii przeciwpłytkowej. Ponadto nowe leki przeciwpłytkowe, takie jak tikagrelor i prasugrel weszły do schematów leczenia ACS. Dotychczas nie przeprowadzono na dużą skalę badań z randomizacją dotyczących oceny tych nowszych leków przeciwpłytkowych u chorych z AF przyjmujących VKA lub NOAC, co wywołuje niepewność, w jaki sposób wykorzystać te środki przeciwzakrzepowe, gdy u pacjenta występuje zarówno CAD (ACS lub stabilna CAD), jak i AF. Według danych EHRA brak dużych badań i duża liczba możliwych kombinacji znajdują odzwierciedlenie w różnorodnych praktykach stosowanych w całej Europie [40]. Dla jasności, zdecydowano się zdefiniować trzy scenariusze kliniczne oraz proste diagramy (patrz niżej), które mogą pomóc w zaplanowaniu leczenia u pacjentów z AF i CAD. Aby uzyskać więcej informacji i kluczowych danych naukowych, należy sięgnąć do pełnych tekstów wytycznych ESC cytowanych powyżej [37-39].

Scenariusz 1: interwencje wieńcowe u pacjentów z AF przyjmujących obecnie NOAC. Podczas gdy w wytycznych zaleca się, aby u pacjentów leczonych VKA utrzymać nieprzerwanie stosowanie tych leków, zarówno w trakcie planowej, jak i pilnej $\mathrm{PCl}$, to podawanie NOAC powinno zostać tymczasowo przerwane do momentu planowych zabiegów i w trakcie ACS, jak miało to miejsce w trakcie trzeciej fazy badań leków. Strategia wykonania PCI (zaplanowanego lub nie) podczas leczenia NOAC jest inna niż w przypadku stosowania VKA z wielu powodów: niepewność co do ostatniej dawki; niepewność co do przestrzegania zaleceń; niepewność co do stopnia antykoagulacji w przypadku braku komercyjnych testów oceny, a co się z tym wiąże - niepewność co do konieczności stosowania dodatkowej okołozabiegowej antykoagulacji; zmienność funkcji nerek (zwłaszcza w okresie ostrym) itp. Ograniczone doświadczenie dotyczące stosowania dabigatranu w małym badaniu drugiej fazy u pacjentów poddawanych planowej PCl sugeruje, że dabigatran może nie zapewnić wystarczającej antykoagulacji w tym wskazaniu [41]. Tymczasowe zaprzestanie stosowania krótkodziałających NOAC umożliwia bezpieczne rozpoczęcie terapii przeciwpłytkowej i standardowego, stosowanego w danych ośrodkach postępowania dotyczącego okołozabiegowego leczenia przeciwzakrzepowego. W ostatnim konsensusie - dokumencie wydanym przez ESC dotyczącym terapii przeciwzakrzepowej u pacjentów z AF poddawanych PCI lub z ACS — nie zaleca się włączania tikagreloru lub prasugrelu w terapii potrójnej, ponieważ związane z tym ryzyko krwawień nie jest znane. Niemniej jednak, możliwe jest stosowanie takich strategii zawierających nowe leki przeciwpłytkowe i (N)OAC w specyficznych przypadkach, takich jak uprzednia zakrzepica w stencie [38].

W omawianym dokumencie [4] zdecydowano się przedstawić zalecenia postępowania zawarte w Scenariuszu 1 (ryc. 3). Szczegółowy opis leczenia w tych wskazaniach można znaleźć w konsensusie ESC [38] oraz wytycznych dotyczących poszczególnych typów ACS i rewaskularyzacji wieńcowej [37]. 
Scenariusz 2: pacjenci z przebytym niedawno ACS ( $<1$ rok) z nowo wykrytym AF. W wytycznych dotyczących postępowania w ACS zaleca się stosowanie DAPT przez okres do roku po ostrym incydencie u osób bez wskazań do doustnego leczenia przeciwzakrzepowego, a ostatnie dane wykazują, że nawet dłuższe stosowanie DAPT może być korzystne [42, 43]. Jeśli w tym okresie rozwija się AF i jest wskazana profilaktyka powikłań zakrzepowo-zatorowych z antykoagulacją, powstaje pytanie o włączenie VKA lub NOAC. Poniższe zalecenia podsumowano $\mathrm{w}$ formie graficznej na rycinie 3 .

Mimo danych o roli małej dawki riwaroksabanu (2,5 lub $5 \mathrm{mg}$ dwa razy na dobę) w zmniejszaniu ryzyka incydentów niedokrwiennych, w tym ryzyka zakrzepicy w stencie u pacjentów z ACS stosujących DAPT (choć bez wpływu na wzrost ryzyka krwawienia), jego protekcyjna rola w zapobieganiu udarom związanym z AF nie została potwierdzona $[44,45]$. Dlatego takie postępowanie z pewnością nie może być wykorzystane u pacjentów z AF z wyższym ryzykiem zakrzepowo-zatorowym, chociaż oczekujemy na wynik badania dotyczącego tego połączenia (PIONEER AF-PCl; NCT01830543).

Scenariusz 3: pacjenci ze stabilną CAD (ACS $\geq 1$ rok), u których rozwija się AF. Pacjenci ze stabilną CAD, u których rozwija się AF, powinni być poddani terapii przeciwzakrzepowej, w zależności od wyniku w skali $\mathrm{CHA}_{2} \mathrm{DS}_{2}$-VASc. Opierając się na wynikach badań, które wykazały, że same VKA są lepsze od ASA u pacjentów po ACS oraz że VKA i ASA mogą nie wykazywać dalszych właściwości protekcyjnych, ale wiążą się z większym ryzykiem krwawienia (patrz wyżej), uznaje się, że antykoagulacja bez dodatkowych środków przeciwpłytkowych jest wystarczająca u większości pacjentów ze stabilną CAD [37, 46, 47].

Czy NOAC są bezpieczną i skuteczną alternatywą w takich przypadkach? W czterech badaniach trzeciej fazy dotyczących NOAC 15-20\% chorych z AF przebyło uprzednio zawał serca. Nie zaobserwowano żadnej interakcji pod względem wyników i bezpieczeństwa między pacjentami z lub bez wcześniejszego zawału serca, chociaż pozostaje niejasne, u ilu chorych utrzymywano terapię przeciwpłytkową i przez jak długi okres. Prawdopodobnie przewaga NOAC (w monoterapii) nad VKA jest zachowana u pacjentów z CAD oraz AF. Również dla dabigatranu zostały zachowane korzyści kliniczne i nie zanotowano wzrostu całkowitej liczby incydentów niedokrwiennych serca. Zostało to również potwierdzone w bardzo dużej obserwacji obejmującej 134000 pacjentów w podeszłym wieku leczonych dabigatranem i VKA, u których nie wykazano zwiększonego ryzyka zawału serca [12, 48]. Nie ma mocnych argumentów za preferowaniem jednego nad drugim NOAC $w$ tym zestawieniu.

\section{Kardiowersja u pacjentów leczonych NOAC}

Na podstawie wytycznych ESC u pacjentów z AF trwającym $>48 \mathrm{~h}$ (lub AF o nieznanym czasie trwania) poddanych kardiowersji skuteczna terapia doustnymi antykoagulantami powinna być stosowana przez co najmniej 3 tygodnie przed kardiowersją lub należy wykonać przezprzełykowe badanie echokardiograficzne (TEE), aby wykluczyć obecność skrzepliny w lewym przedsionku. Po kardiowersji ciągłe leczenie przeciwkrzepliwe doustnymi antykoagulantami jest obowiązkowe przez co najmniej 4 tygodnie, niezależnie od wyniku $\mathrm{CHA}_{2} \mathrm{DS}_{2}$-VASc [49-51]. Należy rozróżnić różne scenariusze: kardiowersję elektryczną u pacjenta leczonego NOAC przez dłuższy czas, który z powodu ataku AF wymaga zastosowania tej procedury, oraz kardiowersję u pacjenta $z$ nowo rozpoznanym AF, chcącego rozpocząć antykoagulację NOAC. W przypadku tego ostatniego scenariusza dostępne są tylko dane u osób z AF trwającym > 48 h, dlatego też rozważono również trzeci scenariusz, z AF trwającym $\leq 48$ h u pacjenta nieleczonego antykoagulantami (ryc. 4).

\section{Kardiowersja u pacjentów z AF trwajacym $>48 \mathrm{~h}$ niestosujacych NOAC}

Strategia kardiowersji AF u pacjenta, który nie jest leczony NOAC, została przeanalizowana $w$ badaniu X-VERT z riwaroksabanem, a badania $z$ innymi NOAC jeszcze trwają. W X-VERT, 1504 pacjentów z AF trwającym > 48 h lub AF o nieznanym czasie trwania zostało skierowanych na kardiowersję i losowo przydzielonych do grupy otrzymującej riwaroksaban lub VKA w stosunku 2:1. Kardiowersja została zastosowana albo wcześnie (z TEE lub bez TEE w przypadku pacjentów leczonych przeciwzakrzepowo za pomocą VKA lub NOAC przez $\geq 3$ tygodnie) lub z opóźnieniem (z trwającą 3-8 tyg. antykoagulacją poprzedzającą kardiowersję). Pacjentom należącym do grupy stosującej riwaroksaban lek został podany przynajmniej $4 \mathrm{~h}$ przed kardiowersją. Spośród badanych 462 pacjentów nieleczonych przeciwkrzepliwie zostało włączonych do strategii wczesnej kardiowersji, z czego 305 otrzymało riwaroksaban. Średni czas wykonania kardiowersji wynosił 1 dzień po randomizacji. Nie było różnicy w liczbie zdarzeń niedokrwiennych lub krwawieniach pomiędzy grupami. Zwraca uwagę, że u 64,7\% osób włączonych do grupy wczesnej kardiowersji wykonano TEE, z których 4,4\% miało skrzepliny w lewym przedsionku i zostało wykluczonych z wczesnej kardiowersji. Dlatego strategia co najmniej jednej dawki NOAC na $\geq 4$ h przed kardiowersją wydaje się być bezpieczna i skuteczna u pacjentów z AF trwającym < $48 \mathrm{~h}$, pod warunkiem, że TEE jest wykonywana przed kardiowersją [52].

\section{Kardiowersja u pacjentów z AF trwającym $\leq 48 \mathrm{~h}$ nieleczonych przeciwkrzepliwie}

Wyniki badania X-VERT nie przyniosły informacji na temat tego, czy przyjęcie co najmniej 1 tabletki NOAC jest odpowiednią strategią u pacjentów z AF trwającym $\leq 48 \mathrm{~h}$, którzy są obecnie często poddawani kardiowersji po zastosowaniu pojedynczej dawki LMWH (z kontynuacją leczenia przeciwkrzepliwego do $\geq 4$ tygodni, zwłaszcza gdy należą 


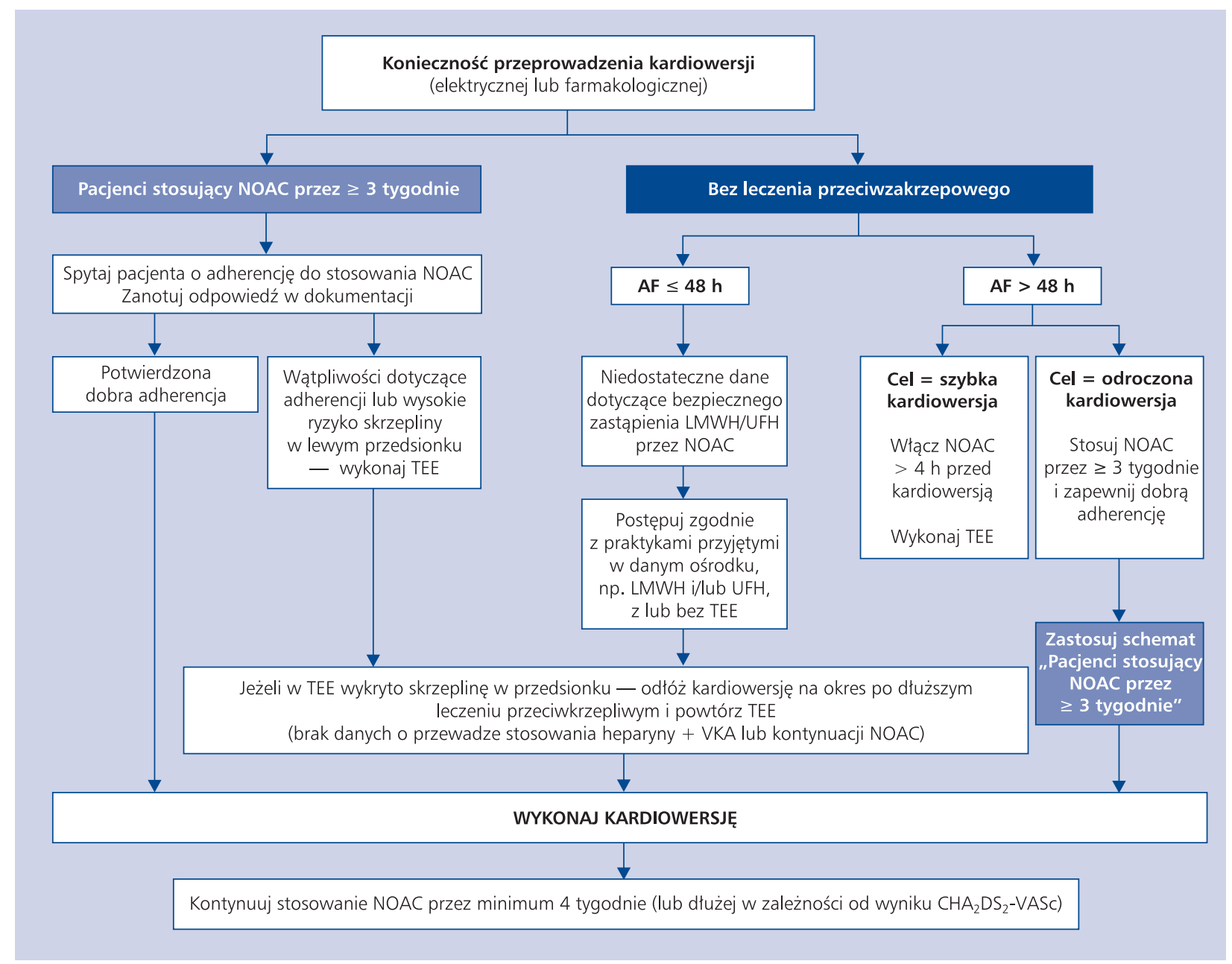

Rycina 4. Postępowanie w przypadku kardiowersji migotania przedsionków (AF) u pacjentów leczonych doustnymi antykoagulantami niebędącymi antagonistami witaminy K (NOAC), w zależności od czasu trwania arytmii i wcześniejszego leczenia przeciwzakrzepowego; LMWH — heparyna drobnocząsteczkowa; TEE — echokardiografia przezprzełykowa; UFH — heparyna niefrakcjonowana; VKA — antagoniści witaminy $\mathrm{K}$

do grupy podwyższonego ryzyka zakrzepowo-zatorowego w skali $\mathrm{CHA}_{2} \mathrm{DS}_{2}-\mathrm{VASC}$ ). Niektórzy z tych pacjentów są włączeni w trwające badania, takie jak ENSURE-AF (z edoksabanem; NCT02072434) oraz EMANATE (z apiksaban; NCT02100228). W przypadku braku dalszych danych zaleca się przestrzeganie aktualnych wytycznych dotyczących stosowania heparyny niefrakcjonowanej/LMWH, z lub bez TEE w tej grupie pacjentów.

\section{Pacjenci z udarem mózgu przyjmujący NOAC} Faza ostra

Nagły krwotok mózgowy (krwotok wewnątrzczaszkowy). Ostatnio opublikowano rekomendacje dotyczące leczenia krwotoku wewnątrzczaszkowego u pacjentów stosujących doustną terapię przeciwkrzepliwą [53, 54].

Poprzez analogię do pacjentów leczonych warfaryną parametry krzepnięcia chorych leczonych NOAC, którzy doznali nagłego krwawienia lub (najwidoczniej) przechodzą zagrażające życiu krwawienie, takie jak krwotok wewnątrzczaszkowy, powinny zostać skorygowane najszybciej jak to możliwe. Zanim dostępne było nowe antidotum dla NOAC, pierwszą strategię leczenia stanowiło zaprzestanie przyjmowania antykoagulantu oraz terapia wspomagająca. Jeśli od przyjęcia leku antykoagulacyjnego minęło $\leq 2 \mathrm{~h}$, można podać doustny węgiel aktywny (patrz wyżej). Informacje na temat zastosowania specyficznych substancji prozakrzepowych, takich jak PCC, aktywowany PCC i aktywowany czynnik VII, w ciężkim krwawieniu związanym z NOAC przedstawiono powyżej. Skuteczność i bezpieczeństwo tej strategii przyjętej dla krwotoku wewnątrzczaszkowego powinny być dokładniej ocenione w badaniach klinicznych [55].

Wśród pacjentów bez udokumentowanego krwawienia lub powiększenia ogniska krwawienia leczenie zachowawcze i obserwacja mogą być zalecane, uwzględniając krótki 
okres półtrwania NOAC. Jeśli szybka normalizacja nie jest przewidywana, należy postępować tak, jak opisano powyżej.

Nagły udar niedokrwienny. Odwołując się do ostatnich wytycznych i oficjalnych zaleceń [4], terapia trombolityczna z użyciem rekombinowanego tkankowego aktywatora plazminogenu (rt-PA), która jest rekomendowana w ciągu 4,5 h od początku wystąpienia objawów udaru niedokrwiennego, nie jest zalecana u pacjentów poddawanych terapii przeciwkrzepliwej (z INR > 1,7, jeśli stosują terapię VKA). Zważywszy na fakt, że okres półtrwania NOAC wynosi 8-17 h, leczenie trombolityczne nie może być rozpoczęte przed 24(-48) godzinami od przyjęcia ostatniej dawki leku przeciwkrzepliwego (2-4 okresów półtrwania zależnie od parametrów nerkowych), uwzględniając spodziewane korzyści z trombolizy przeważające nad ryzykiem z nią związanym. Jest to bezwzględna rekomendacja, która jeszcze nie została potwierdzona w badaniach klinicznych. W przypadku nieznajomości czasu przyjęcia ostatniej dawki leku przeciwkrzepliwego wydłużony APTT (dla dabigatranu) wskazuje na to, że pacjent znajduje się pod wpływem terapii przeciwkrzepliwej (patrz wyżej) i leczenie trombolityczne nie powinno być rozpoczęte. Niezawodny biomarker dla NOACs, który mógłby być mierzony przy przyjęciu na szpitalny oddział ratunkowy, wciąż nie jest dostępny. Dopóki nie zostaną wynalezione czułe i szybkie testy dla poszczególnych NOAC, odradza się leczenie trombolityczne u pacjentów z nieznanym statusem przeciwkrzepliwym. Ponadto tylko w pojedynczych przypadkach, w których w dedykowanych testach potwierdzono koagulację znajdującą się w zakresach referencyjnych, można rozważyć wykorzystanie rt-PA. Zachęca się, aby w sytuacjach pilnych stosować proste w użyciu testy bezpośrednie. Nie ma danych (nawet przedklinicznych), czy zastosowanie specyficznego antidotum dla NOAC pozwoli na szybszą trombolizę. W badaniu RE-VERSE AD dopuszczalne było zastosowanie idarucizumabu przed leczeniem trombolitycznym [24].

\section{Postępowanie po fazie ostrej}

Krwawienie wewnątrzczaszkowe. Jak wspomniano, brakuje wytycznych opartych na badaniach dotyczących NOAC na temat krwawienia wewnątrzczaszkowego. Zawsze będzie to bardzo trudna indywidualna decyzja odnośnie do przywrócenia lub też nieprzywrócenia leczenia przeciwkrzepliwego u pacjentów po krwotoku wewnątrzczaszkowym związanym z leczeniem przeciwkrzepliwym. Poprzez analogię do zastosowania VKA, przyjmowanie NOAC może być rozpoczęte po 4-8 tygodniach, jeśli ryzyko sercowo-zatorowe jest wysokie, a ryzyko nowego krwawienia wewnątrzczaszkowego oceniono na niskie $[53,54]$

Krwiaki nadtwardówkowe są zawsze spowodowane urazem i przebiegają ze złamaniami kości czaszki. W takich przypadkach bezpieczne wydaje się ponowne rozpoczęcie leczenia przeciwkrzepliwego po 4 tygodniach, mimo braku konkretnych danych. To samo dotyczy urazowych krwiaków podtwardówkowych, z wyjątkiem 1/3 pacjentów nadużywających alkoholu. W przypadku samoistnych krwiaków podtwardówkowych w kontekście niekontrolowanego INR (np. > 3) leczenie przeciwkrzepliwe może być rozpoczęte po 4 tygodniach. Jeśli INR był w normie lub pacjent nie stosował terapii przeciwkrzepliwej, doustne leki przeciwkrzepliwe są przeciwwskazane.

Niefarmakologiczna prewencja, taka jak okluzja uszka lewego przedsionka, powinna być rozważona jako potencjalny substytut dla wznowienia długotrwałego leczenia przeciwkrzepliwego w przypadku przeciwwskazań [9, 51].

Udar niedokrwienny. Kontynuowanie lub zaprzestanie terapii NOAC zależy od rozległości i ciężkości udaru. Jeśli u pacjentów z umiarkowanym udarem rozległość ogniska udarowego nie zwiększa istotnie ryzyka wczesnego wtórnego krwawienia wewnątrzczaszkowego, podanie NOAC powinno być kontynuowane analogicznie do terapii VKA. Mając na uwadze fakt, że NOAC charakteryzują się szybszym początkiem działania w porównaniu z VKA, terapia pomostowa heparyną (niefrakcjonowaną lub LMWH) nie jest wymagana. Kwas acetylosalicylowy nie znalazł miejsca w prewencji wtórnej udaru $[9,51]$.

Nie ma wyników badań klinicznych dotyczących momentu wznowienia leczenia przeciwkrzepliwego po przejściowym ataku niedokrwiennym (TIA). Ponadto rekomendacje na temat rozpoczęcia terapii lekami przeciwkrzepliwymi bazują na opinii opartej na konsensusie według znanej zasady "1-3-6-12 dni” — u pacjentów z TIA i AF doustne leczenie przeciwkrzepliwe może być rozpoczęte pierwszego dnia, a u chorych, którzy stosowali leczenie przeciwkrzepliwe, terapia może być kontynuowana. $U$ pacjentów z łagodnym udarem [National Institute of Heath Stroke Scale (NIHSS) < 8] doustne leczenie przeciwkrzepliwe powinno być rozpoczęte po 3 dniach lub po wykluczeniu krwawienia wewnątrzczaszkowego metodą obrazową (CT lub MRI). U osób z umiarkowanym udarem (NIHSS 8-16) terapia przeciwkrzepliwa może zostać rozpoczęta po 5-7 dniach, a w przypadku ciężkich udarów (NIHSS > 16) - po 12-14 dniach. W ostatnim przypadku powtórzenie obrazowania struktur mózgu powinno być przeprowadzone w celu wykluczenia istotnej transformacji w udar krwotoczny pierwotnego udaru niedokrwiennego (ryc. 5). Trwające badania, takie jak RE-SPECT ESUS (NCT02239120) wprowadziły tę empiryczną "zasadę" jako spodziewaną strategię, która jest warta rekomendacji.

Przejściowy atak niedokrwienny o pochodzeniu sercowo-zatorowym. $U$ pacjentów z TIA leczenie przeciwkrzepliwe za pomocą NOAC powinno zostać rozpoczęte niezwłocznie. Uwzględniając szybkie rozpoczęcie leczenia NOAC, pomostowa terapia heparyną niefrakcjonowaną lub LMWH nie jest zalecana. Kwas acetylosalicylowy nie stanowi alternatywy: u osób z AF, u których terapia prewencyjna VKA nie jest odpowiednia, inhibitor czynnika Xa — apiksaban 


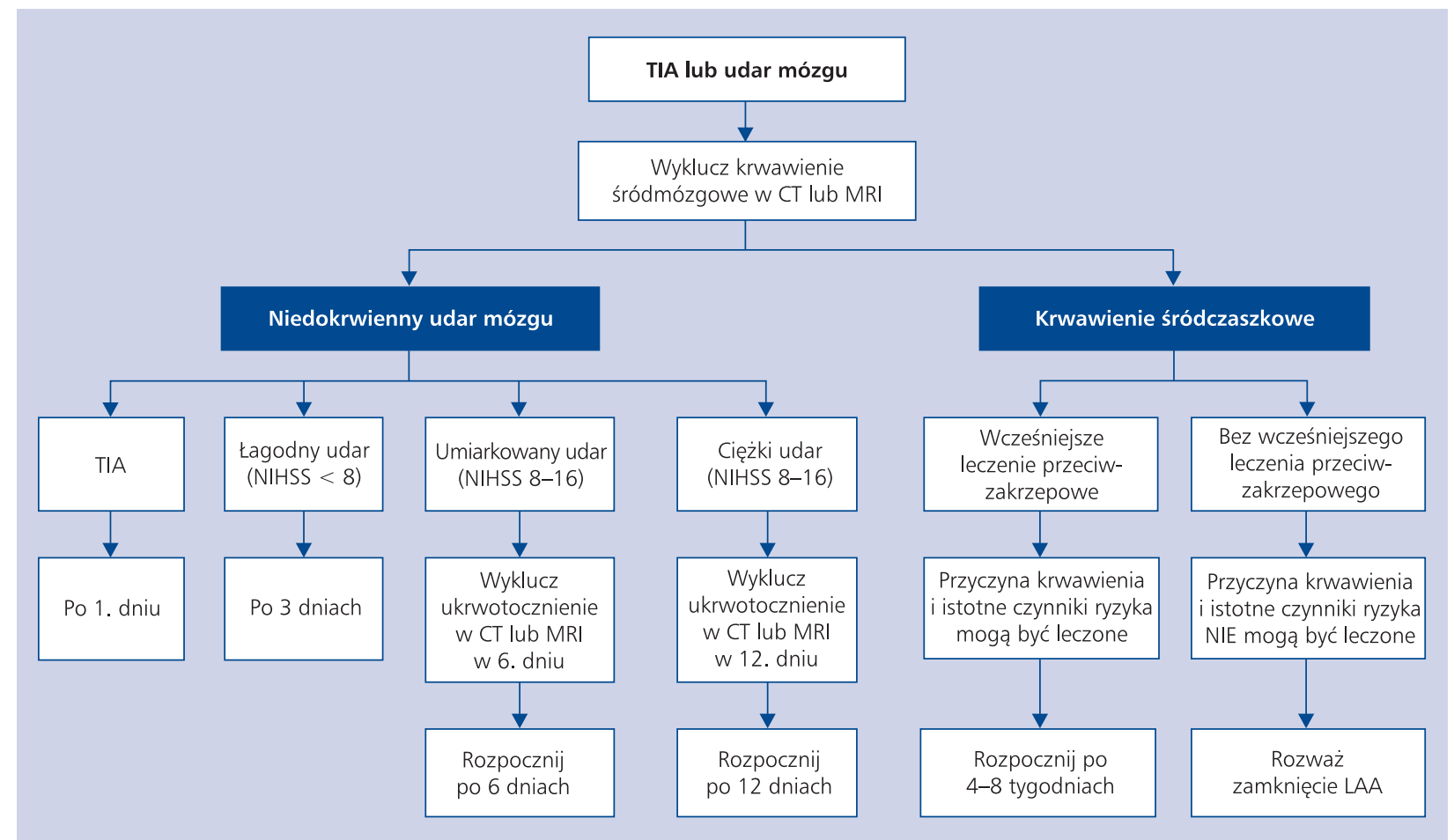

Rycina 5. Zasady wdrażania lub ponownego włączenia leczenia przeciwzakrzepowego po udarze mózgu lub przemijającym ataku niedokrwiennym (TIA) bądź krwawieniu wewnątrzczaszkowym; CT — tomografia komputerowa; LAA — uszko lewego przedsionka; MRI — obrazowanie metodą rezonansu magnetycznego

przewyższa ASA w prewencji epizodów udarowych, charakteryzując się takim samym ryzykiem wywołania krwawienia [56].

Migotanie przedsionków i współistniejąca miażdżyca tętnic szyjnych. Pacjenci z AF i rozpoznaną miażdżycą tętnic szyjnych z łagodną bezobjawową stenozą mogą być leczeni tylko preparatami przeciwkrzepliwymi, bez konieczności dodatkowej terapii przeciwpłytkowej, tak jak w stabilnej CAD (patrz wyżej). Pacjenci z AF i objawową stenozą trzeciego stopnia tętnic szyjnych wewnętrznych powinni być zoperowani bez implantacji stentu. Pozwala to uniknąć wydłużonej terapii potrójnej z wysokim ryzykiem dużego krwawienia, jak u chorych z implantowanym stentem. U pacjentów podlegających endarterektomii dodanie ASA jest zalecane niezwłocznie przed zabiegiem oraz do 10 dni po jego przeprowadzeniu [57].

\section{NOAC VS. VKA U PACJENTÓW Z AF I WSPÓŁISTNIEJĄCYM NOWOTWOREM ZŁOŚLIWYM - UWAGI PRAKTYCZNE}

1. Pacjenci z nowotworem i AF wymagają wielodyscyplinarnej opieki kardiologów i onkologów, w tym starannego planowania leczenia przeciwzakrzepowego.

2. Obecność nowotworu u pacjentów z AF zwiększa ryzyko udaru mózgu. Jeśli chorzy z AF wcześniej stosowali już terapię NOAC, jej kontynuowanie może być możliwe, nawet u osób z nowotworami złośliwymi, które są poddane średnio mielosupresyjnym terapiom. Należy wziąć pod uwagę możliwe interakcje z lekami wpływającymi na stężenia NOAC w osoczu (np. z antybiotykami lub lekami przeciwgrzybiczymi).

3. W przypadku konieczności rozpoczęcia leczenia przeciwzakrzepowego u pacjentów z nowotworem złośliwym, u których rozwinęło się AF, leczenie VKA lub heparyną powinno być preferowane nad NOAC, ze względu na doświadczenie kliniczne z tymi substancjami, możliwość ich ścisłego monitorowania i opcje odwrócenia działania.

4. Na podstawie danych dotyczących chorych z zatorowością żylną terapia NOAC wg schematów dawkowania właściwych dla AF będzie również zapobiegać zatorowości żylnej. Dlatego też nie ma dodatkowej potrzeby rutynowego leczenia przeciwzakrzepowego u pacjentów z nowotworem.

5. W przypadku pacjentów z chorobą nowotworową leczonych NOAC, u których trzeba przeprowadzić operację guza, stosuje się te same zasady co u innych osób poddawanych planowej operacji (patrz wyżej).

6. U pacjentów poddawanych chemioterapii lub radioterapii, bez wyraźnego efektu mielosupresyjnego, korzystnie jest kontynuować leczenie NOAC, pod warunkiem, że dawka jest przystosowana do przewidywanych modyfi- 
kacji terapii wywołanych przez zmiany funkcjonowania narządów (zwłaszcza wątroby i nerek).

7. Jeśli planowana jest chemioterapia mielosupresyjna lub radioterapia, wielodyscyplinarny zespół z udziałem kardiologów i onkologów powinien rozważyć czasowe zmniejszenie dawki lub zaprzestanie leczenia NOAC. Szczegółowe zasady monitorowania powinny być rozpatrywane łącznie i obejmować: (a) powtarzane, pełne badanie morfologii krwi, w tym płytek krwi; (b) staranne badanie klinicznych objawów krwawienia; (c) regularne monitorowanie czynności nerek i wątroby.

8. Jak wspomniano, ochrona żołądka z zastosowaniem IPP lub antagonistów H2 może być rozważona u wszystkich pacjentów leczonych preparatami przeciwzakrzepowymi.

9. Pacjentów z nowotworem leczonych NOAC należy poinstruować, aby dokładnie monitorowali objawy krwawienia (wybroczyny, krwioplucie i czarne stolce) oraz, aby skontaktowali się ze służbami medycznymi w razie ich wystąpienia.

Konflikt interesów: nie zgłoszono

\section{Piśmiennictwo}

1. Heidbuchel H, Verhamme P, Alings M et al. European Heart Rhythm Association Practical Guide on the use of new oral anticoagulants in patients with non-valvular atrial fibrillation. Europace, 2013; 15: 625-651.

2. Szymański FM. Practical guide on the use of new oral anticoagulants in nonvalvular atrial fibrillation patients. Kardiol Pol, 2013; 71, supl. VIII: 205-216.

3. Husted S, de Caterina R, Andreotti F et al.; ESC Working Group on Thrombosis Task Force on Anticoagulants in Heart Disease. Non-vitamin K antagonist oral anticoagulants (NOACs): no longer new or novel. Thromb Haemost, 2014; 111: 781-782.

4. Heidbuchel H, Verhamme P, Alings M et al. Updated European Heart Rhythm Association Practical Guide on the use of non-vitamin $\mathrm{K}$ antagonist anticoagulants in patients with non-valvular atrial fibrillation. Europace, 2015; 17: 1467-1507.

5. De Caterina R, Camm AJ. What is 'valvular' atrial fibrillation? A reappraisal. Eur Heart J, 2014; 35: 3328-3335.

6. The management of atrial fibrillation: NICE Guideline 180 (United Kingdom National Institute for Health and Care Excellence). https://www.nice.org.uk/guidance/cg180. June 2014.

7. Lane DA, Aguinaga L, Blomstrom-Lundqvist $\mathrm{C}$ et al. Cardiac tachyarrhythmias and patient values and preferences for their management: the European Heart Rhythm Association (EHRA) consensus document endorsed by the Heart Rhythm Society (HRS), Asia Pacific Heart Rhythm Society (APHRS), and Sociedad Latinoamericana de Estimulacion Cardiaca y Electrofisiologia (SOLEACE). Europace 2015;doi:10.1093/europace/euv233.

8. Heidbuchel $\mathrm{H}$, Berti D, Campos $\mathrm{M}$ et al. Implementation of non-vitamin $\mathrm{K}$ antagonist oral anticoagulants in daily practice: the need for comprehensive education for professionals and patients. Thromb J, 2015; 13: 22.

9. Camm AJ, Lip GY, De Caterina R et al. 2012 focused update of the ESC Guidelines for the management of atrial fibrillation: an update of the 2010 ESC Guidelines for the management of atrial fibrillation. Europace, 2012; 14: 1385-1413.

10. Hendriks JM, de Wit R, Crijns HJ et al. Nurse-led care vs. usual care for patients with atrial fibrillation: results of a randomized trial of integrated chronic care vs. routine clinical care in ambulatory patients with atrial fibrillation. Eur Heart J, 2012; 33: 2692-2699.

11. Berti D, Hendriks JM, Brandes A et al. A proposal for interdisciplinary, nurse-coordinated atrial fibrillation expert programmes as a way to structure daily practice. Eur Heart J, 2013; 34: 2725-2730.

12. Graham DJ, Reichman ME, Wernecke M et al. Cardiovascular, bleeding, and mortality risks in elderly Medicare patients treated with dabigatran or warfarin for nonvalvular atrial fibrillation. Circulation, 2015; 131: 157-164.

13. Ruff CT, Giugliano RP, Braunwald E et al. Transition of patients from blinded study drug to open-label anticoagulation: the ENGAGE AF-TIMI 48 trial. J Am Coll Cardiol, 2014; 64: 576-584.

14. Olesen JB, Lip GYH, Kamper A-L et al. Stroke and bleeding in atrial fibrillation with chronic kidney disease. N Engl J Med, 2012; 367: 625-635.

15. Piccini JP, Stevens SR, Chang Y et al. Renal dysfunction as a predictor of stroke and systemic embolism in patients with nonvalvular atrial fibrillation: validation of the R2CHADS2 Index in the ROCKET AF (Rivaroxaban Once-daily, oral, direct factor Xa inhibition Compared with vitamin $\mathrm{K}$ antagonism for prevention of stroke and Embolism Trial in Atrial Fibrillation) and ATRIA (AnTicoagulation and Risk factors In Atrial fibrillation) Study Cohorts. Circulation, 2013; 127: 224-232.

16. Camm AJ, Savelieva I. "R" for "renal" and for "risk": refining risk stratification for stroke in atrial fibrillation. Circulation, 2013; 127: 169-171.

17. Hart RG, Pearce LA, Asinger RW, Herzog CA. Warfarin in atrial fibrillation patients with moderate chronic kidney disease. Clin J Am Soc Nephrol, 2011; 6: 2599-2604.

18. Nielsen PB, Lane DA, Rasmussen LH et al. Renal function and nonvitamin $\mathrm{K}$ oral anticoagulants in comparison with warfarin on safety and efficacy outcomes in atrial fibrillation patients: a systemic review and meta-regression analysis. Clin Res Cardiol, 2015; 104: 418-429.

19. Green R, Grierson R, Sitar DS, Tenenbein M. How long after drug ingestion is activated charcoal still effective? J Toxicol Clin Toxicol, 2001; 39: 601-605.

20. Wang X, Mondal S, Wang J et al. Effect of activated charcoal on apixaban pharmacokinetics in healthy subjects. Am J Cardiovasc Drugs, 2014; 14: 147-154.

21. Hylek EM, Held C, Alexander JH et al. Major bleeding in patients with atrial fibrillation receiving apixaban or warfarin: the ARISTOTLE Trial (Apixaban for Reduction in Stroke and Other Thromboembolic Events in Atrial Fibrillation): Predictors, Characteristics, and Clinical Outcomes. J Am Coll Cardiol, 2014; 63: 2141-2147.

22. Majeed A, Hwang HG, Connolly SJ et al. Management and outcomes of major bleeding during treatment with dabigatran or warfarin. Circulation, 2013; 128: 2325-2332.

23. Hanley JP. Warfarin reversal. J Clin Pathol, 2004; 57: 1132-1139.

24. Pollack CV Jr, Reilly PA, Eikelboom J et al. Idarucizumab for dabigatran reversal. N Engl J Med, 2015; 373: 511-520.

25. Glund S, Stangier J, Schmohl M et al. Safety, tolerability, and efficacy of idarucizumab for the reversal of the anticoagulant effect of dabigatran in healthy male volunteers: a randomised, placebo-controlled, doubleblind phase 1 trial. Lancet, 2015; 386: 680-690.

26. Glund S, Stangier J, Schmohl M et al. Idarucizumab, a specific antidote for dabigatran: immediate, complete and sustained reversal of dabigatran induced anticoagulation in elderly and renally impaired subjects. Blood, 2014; 124: 344.

27. Levi M, Eerenberg E, Kamphuisen PW. Bleeding risk and reversal strategies for old and new anticoagulants and antiplatelet agents. J Thromb Haemost, 2011; 9: 1705-1712. 
28. Healey JS, Eikelboom J, Douketis J et al. Periprocedural bleeding and thromboembolic events with dabigatran compared with warfarin: results from the Randomized Evaluation of Long-Term Anticoagulation Therapy (RE-LY) randomized trial. Circulation, 2012; 126: 343-348.

29. Camm AJ, Kirchhof P, Lip GY et al. Guidelines for the management of atrial fibrillation: the Task Force for the Management of Atrial Fibrillation of the European Society of Cardiology (ESC). Europace, 2010; 12: 1360-1420.

30. Beyer-Westendorf J, Gelbricht V, Forster K et al. Peri-interventional management of novel oral anticoagulants in daily care: results from the prospective Dresden NOAC registry. Eur Heart J, 2014; 35: 1888-1896.

31. Douketis JD, Spyropoulos AC, Kaatz S et al. Perioperative bridging anticoagulation in patients with atrial fibrillation. $\mathrm{N}$ Engl J Med, 2015; 373: 823-833.

32. Sie P, Samama CM, Godier A et al. Surgery and invasive procedures in patients on long-term treatment with direct oral anticoagulants: thrombin or factor-Xa inhibitors. Recommendations of the working group on perioperative haemostasis and the french study group on thrombosis and haemostasis. Arch Cardiovasc Dis, 2011; 104: 669-676.

33. Sticherling C, Marin F, Birnie D et al. Antithrombotic management in patients undergoing electrophysiological procedures: a European Heart Rhythm Association (EHRA) position document endorsed by the ESC Working Group Thrombosis, Heart Rhythm Society (HRS), and Asia Pacific Heart Rhythm Society (APHRS). Europace, 2015; 17: 1197-1214.

34. Zahir H, Brown KS, Vandell AG et al. Edoxaban effects on bleeding following punch biopsy and reversal by a 4-factor prothrombin complex concentrate. Circulation, 2015; 131: 82-90.

35. Eerenberg ES, Kamphuisen PW, Sijpkens MK et al. Reversal of rivaroxaban and dabigatran by prothrombin complex concentrate: a randomized, placebo-controlled, crossover study in healthy subjects. Circulation, 2011; 124: 1573-1579.

36. Lopes RD, Pieper KS, Horton JR et al. Shortand long-term outcomes following atrial fibrillation in patients with acute coronary syndromes with or without ST-segment elevation. Heart, 2008; 94: 867-873.

37. Windecker S, Kolh P, Alfonso F et al. 2014 ESC/EACTS Guidelines on myocardial revascularization: The Task Force on Myocardial Revascularization of the European Society of Cardiology (ESC) and the European Association for Cardio-Thoracic Surgery (EACTS). Eur Heart J, 2014; 35: 2541-2619.

38. Lip GY, Windecker S, Huber K et al. Management of antithrombotic therapy in atrial fibrillation patients presenting with acute coronary syndrome and/or undergoing percutaneous coronary or valve interventions: a joint consensus document of the European Society of Cardiology Working Group on Thrombosis, European Heart Rhythm Association (EHRA), European Association of Percutaneous Cardiovascular Interventions (EAPCI) and European Association of Acute Cardiac Care (ACCA) endorsed by the Heart RhythmSociety (HRS) and Asia-Pacific Heart Rhythm Society (APHRS). Eur Heart J, 2014; 35: 3155-3179.

39. Gorenek B, Blomstrom Lundqvist C, Brugada Terradellas J et al. Cardiac arrhythmias in acute coronary syndromes: position paper from the joint EHRA, ACCA, and EAPCI task force. Europace, 2014; 16: 1655-1673.

40. Potpara TS, Lip GY, Dagres N et al. Management of acute coronary syndrome in patients with non-valvular atrial fibrillation: results of the European Heart Rhythm Association Survey. Europace, 2014; 16: 293-298.
41. Vranckx P, Verheugt FW, de Maat MP et al. A randomized study of dabigatran in elective percutaneous coronary intervention in stable coronary artery disease patients. EuroIntervention, 2013; 8: 1052-1060.

42. Mauri L, Kereiakes DJ, Yeh RW et al. Twelve or 30 months of dual antiplatelet therapy after drug-eluting stents. N Engl J Med, 2014; 371: 2155-2166.

43. Bonaca MP, Bhatt DL, Cohen M et al. Long-term use of ticagrelor in patients with prior myocardial infarction. $\mathrm{N}$ Engl J Med, 2015; 372: $1791-1800$

44. Mega JL, Braunwald E, Wiviott SD et al. Rivaroxaban in patients with a recent acute coronary syndrome. N Engl J Med, 2012; 366: 9-19.

45. Gibson CM, Chakrabarti AK, Mega J et al. Reduction of stent thrombosis in patients with acute coronary syndromes treated with rivaroxaban in ATLAS-ACS 2 TIMI 51. J Am Coll Cardiol, 2013; 62: 286-290.

46. Lamberts M, Gislason GH, Lip GY et al. Antiplatelet therapy for stable coronary artery disease in atrial fibrillation patients taking an oral anticoagulant: a nationwide cohort study. Circulation, 2014; 129: 1577-1585.

47. Hamm CW, Bassand JP, Agewall S et al. ESC Guidelines for the management of acute coronary syndromes in patients presenting without persistent ST-segment elevation: The Task Force for the management of acute coronary syndromes (ACS) in patients presenting without persistent ST-segment elevation of the European Society of Cardiology (ESC). Eur Heart J, 2011; 32: 2999-3054.

48. Hohnloser SH, Oldgren J, Yang S et al. Myocardial ischemic events in patients with atrial fibrillation treated with dabigatran or warfarin in the RE-LY (Randomized Evaluation of Long-Term Anticoagulation Therapy) trial. Circulation, 2012;125: 669-676.

49. Nagarakanti R, Ezekowitz MD, Oldgren J et al. Dabigatran versus warfarin in patients with atrial fibrillation: an analysis of patients undergoing cardioversion. Circulation, 2011; 123: 131-136.

50. January CT, Wann LS, Alpert JS et al. 2014 AHA/ACC/HRS guideline for the management of patients with atrial fibrillation: a report of the American College of Cardiology/American Heart Association Task Force on practice guidelines and the Heart Rhythm Society. Circulation, 2014; 130: e199-e267.

51. Camm AJ, Kirchhof P, Lip GY et al. Guidelines for the management of atrial fibrillation: the Task Force for the Management of Atrial Fibrillation of the European Society of Cardiology (ESC). Europace, 2010; 12: 1360-1420.

52. Cappato R, Ezekowitz MD, Klein AL et al. Rivaroxaban vs. vitamin $\mathrm{K}$ antagonists for cardioversion in atrial fibrillation. Eur Heart J, 2014; 35: 3346-3355.

53. Morgenstern LB, Hemphill JC 3rd, Anderson C et al. Guidelines for the management of spontaneous intracerebral hemorrhage: a guideline for healthcare professionals from the American Heart Association/American Stroke Association. Stroke, 2010; 41: 2108-2129.

54. Steiner T, Al-Shahi Salman R, Beer R et al. European Stroke Organisation (ESO) guidelines for the management of spontaneous intracerebral hemorrhage. Int J Stroke, 2014; 9: 840-855.

55. Hankey GJ. Intracranial hemorrhage and novel anticoagulants for atrial fibrillation: what have we learned? Curr Cardiol Rep, 2014; 16: 480

56. Connolly SJ, Eikelboom J, Joyner C et al. Apixaban in patients with atrial fibrillation. N Engl J Med, 2011; 364: 806-817.

57. Taylor DW, Barnett HJ, Haynes RB et al. Low-dose and high-dose acetylsalicylic acid for patients undergoing carotid endarterectomy: a randomised controlled trial. ASA and Carotid Endarterectomy (ACE) Trial Collaborators. Lancet, 1999; 353: 2179-2184. 